\title{
Regulation of TrkA and ChAT Expression in Developing Rat Basal Forebrain: Evidence That Both Exogenous and Endogenous NGF Regulate Differentiation of Cholinergic Neurons
}

\author{
Yiwen Li, ${ }^{1}$ David M. Holtzman, ${ }^{1}$ Lawrence F. Kromer, ${ }^{2}$ David R. Kaplan, ${ }^{3}$ Jane Chua-Couzens, ${ }^{1}$ Douglas $O$. \\ Clary, ${ }^{1}$ Beat Knüsel, ${ }^{4}$ and William C. Mobley ${ }^{1}$ \\ 'Departments of Neurology, Pediatrics, and Physiology, Howard Hughes Medical Institute, and the Neuroscience \\ Program, University of California at San Francisco, San Francisco, California 94143, 2Department of Cell Biology, \\ Georgetown University Medical Center, Washington, DC 20007, ${ }^{3}$ Eukaryotic Signal Transduction Group, ABL-Basic \\ Research Program, NCl-Frederick Cancer Research and Development Center, Frederick, Maryland 21702, and \\ ${ }^{4}$ Division of Neurogerontology, Andrus Gerontology Center, and Department of Biological Sciences, University of \\ Southern California, Los Angeles, California 90089
}

TrkA is a receptor tyrosine kinase whose activation transduces NGF signaling. TrkA expression has been demonstrated in NGF-responsive adult basal forebrain cholinergic neurons (BFCNs). $\mathrm{S}$

everal lines of evidence have suggested that endogenous NGF plays a role in the development and differentiation of these neurons. We examined TrkA expression during development. TrkA mRNA and protein were present in basal forebrain neurons during the entire postnatal period; the distribution of neurons bearing these markers was identical to that for those containing choline acetyltransferase (ChAT) mRNA, suggesting that, as in the adult, TrkA gene expression is localized to BFCNs. The expression of TrkA and ChAT followed a very similar temporal pattern, suggesting regulation by the same factor(s). We discovered that NGF administration in vivo activated TrkA receptors, and increased both TrkA and ChAT mRNA; conversely, anti-NGF infusions suppressed expression of both genes. These results suggest that endogenous NGF regulates expression of TrkA and ChAT. Finally, while NGF infusion increased the size of developing BFCNs, NGF antibodies inhibited the normal developmental increase. The results are evidence that endogenous NGF acts on developing BFCNs to enhance gene expression and cellular differentiation.

[Key words: NGF, NGF receptor, TrkA, ChAT, basal forebrain cholinergic neurons (BFCNs), development, NGF antiserum]

NGF binds to low and high affinity receptors on responsive neurons in both the PNS and the CNS (Sutter et al., 1979; Vale and Shooter, 1985; Richardson et al., 1986; Mobley et al., 1989; Altar et al., 1991; Chao, 1992; Meakin and Shooter, 1992). Binding to high affinity sites mediates biological activity (Sutter et

\footnotetext{
Received Apr. 20, 1994; revised Sept. 12, 1994; accepted Oct. 21, 1994.

We thank Drs. Rong Wen and Emmett Cunningham, Jr., for discussion, Ms. Janice S. Valletta and Robin S. Cooper for technical support, and Ms. Dianne Esson for secretarial assistance. This work was supported by National Institutes of Health Grants NS 31445 (L.F.K.) and NS 24054 and AG 08938 (W.C.M.).

Correspondence should be addressed to William C. Mobley, Department of Neurology, M-794, University of California, San Franscisco, San Francisco, CA 94143-0114.

Copyright $(\mathcal{C} 1995$ Society for Neuroscience $\quad 0270-6474 / 95 / 152888-18 \$ 05.00 / 0$
}

al., 1979; Bernd and Greene, 1984; Green and Greene, 1986; Meakin and Shooter, 1992). The exact composition of high affinity receptors is disputed (Bothwell, 1991; Hempstead et al., 1991; Chao, 1992; Jing et al., 1992), but the receptor tyrosine kinase TrkA appears to mediate NGF actions (Kaplan et al., 1991a,b; Klein et al., 1991; Meakin and Shooter, 1991a,b; Ip et al., 1993). To date, all NGF responsive populations have been shown to express the TrkA gene (Grimes et al., 1993; Holtzman et al., 1994). In responsive cells, NGF binds to TrkA and through dimerization, causes activation of its kinase and autophosphorylation (Kaplan et al., 1991a,b; Klein et al., 1991; Meakin and Shooter, 1991a,b; Jing et al., 1992). A cascade of intracellular events then ensues that appears to be similar to that seen after activation of other receptor tyrosine kinases (Kim et al., 1991; Ohmichi et al., 1991, 1992; Thomas et al., 1991; Vetter et al., 1991; Carter and Downes, 1992; Raffioni and Bradshaw, 1992; Soltoff et al., 1992; Fantl et al., 1993). One interesting consequence of NGF actions is upregulation of TrkA gene expression (Holtzman et al., 1992a; Meakin et al., 1992). The physiological consequences of increased TrkA expression may be significant. In vitro, there is increased binding and signaling through this receptor (Hempstead et al., 1992; Zhou, Grimes, Valletta, and Mobley, unpublished observation). Thus, understanding TrkA regulation is important not only for defining where and when NGF acts, but also for deducing the significance of NGF actions on the biology of responsive cells.

Herein, we have characterized the regulation of TrkA expression in the developing rat basal forebrain. TrkA mRNA and protein were present in basal forebrain neurons throughout postnatal development. The distribution of TrkA positive cells was identical to that for neurons containing the mRNA for ChAT, the specific cholinergic neurotransmitter synthetic enzyme. This suggested that TrkA gene expression was localized to BFCNs. Expression of the gene for TrkA was highly regulated; the pattern was very similar to that for ChAT. This raised the possibility that TrkA and ChAT gene expression were regulated by the same factor(s). Three lines of evidence supported the view that NGF is one such factor. First, NGF injections induced tyrosine phosphorylation of TrkA in the developing basal forebrain. Second, exogenous NGF induced an increase in both $\operatorname{Trk} \Lambda$ and $\operatorname{Ch} \Lambda \mathrm{T}$ mRNA levels. Third, administration of specific anti-NGF anti- 
bodies decreased expression for both genes. Significantly, NGF antibody infusion also suppressed the normal developmental increase in BFCN cell size. Our findings indicate that NGF is a neurotrophic factor for developing BFCNs. They point to NGF regulation of TrkA as important for the normal differentiation of these cells.

\section{Materials and Methods}

In situ hybridization (ISHH). Sprague-Dawley rats (Bantin and Kingman, Richmond, CA) were used in all experiments. Coronal sections $(18 \mu \mathrm{m})$ from fresh-frozen brains were cut at $-18^{\circ} \mathrm{C}$ on a cryostat. Sections were thaw mounted onto gelatin-coated slides and stored at $-70^{\circ} \mathrm{C}$. For developmental studies, three to five brains were analyzed in cach age group.

A 434 bp mouse TrkA cDNA subcloned into pGEM-7Zf (Promega Biotech, Madison, WI; gift of L. F. Parada) or a $2.3 \mathrm{~kb}$ rat ChAT cDNA subcloned in pSPT18 (Pharmacia, Piscataway, NJ; gift of J. Mallet) were used for synthesis of ${ }^{35} \mathrm{~S}$ labeled antisense or sense RNA probes as described (Holtzman et al., 1992a). Probe preparation used a Promega Riboprobe Kit (Promega Biotech). The linearized DNA template $(2 \mu \mathrm{g})$ was incubated in $20 \mu \mathrm{l}$ transcription buffer containing RNAsin (40 U); 10 mM DTT; 0.5 mM each rATP, rGTP, rCTP; $10 \mu \mathrm{M}$ cold rUTP; $50 \mu \mathrm{Ci}$ of ${ }^{35} \mathrm{~S}$-UTP $(1225 \mathrm{Ci} / \mathrm{mm}$, Dupont $/ \mathrm{New}$ England Nuclear, Wilmington, DE); and $20 \mathrm{U}$ of RNA polymerase. The incubation proceeded for $2 \mathrm{hr}$ at $37^{\circ} \mathrm{C}$. The DNA template was digested with RNase-free DNase for $10 \mathrm{~min}$ at $37^{\circ} \mathrm{C}$. The cRNA probe was then isolated by phenol/chloroform extraction and reduced in size to an average length of 200 nucleotides by alkaline hydrolysis, all as deseribed previously (Springer et al., 1990).

We used the same procedures and hybridization conditions for all probes (Springer et al., 1990; Holtzman et al., 1992a). Prehybridization steps consisted of fixation of tissue sections in $3 \%$ buffered paraformaldehyde for $15 \mathrm{~min}$ at room temperature, acetylation in $0.1 \mathrm{M}$ triethanolamine $(\mathrm{pH} 8.0)$ and acetic anhydride $(0.25 \%)$ for $10 \mathrm{~min}$, incubation in $0.1 \mathrm{M}$ Tris/glycine buffer ( $\mathrm{pH} 7.0$ ) for $30 \mathrm{~min}$, and dehydration in graded alcohols followed by air drying. Each section was then hybridized using $30 \mu \mathrm{l}$ of hybridization buffer containing $2 \mathrm{ng}$ of ${ }^{35} \mathrm{~S}$ labeled RNA probe at $50^{\circ} \mathrm{C}$ for $4 \mathrm{hr}$. The hybridization buffer was $40 \%$ deionized formamide, $4 \times \mathrm{SSC}, 1 \mathrm{mg} / \mathrm{ml}$ yeast $\mathrm{RNA}, 1 \mathrm{mg} / \mathrm{ml}$ salmon sperm DNA, $8 \%$ dextran sulfate, 10 mM DTT, and $5 \times$ Denhardt's solution. Posthybridization steps consisted of incubating slides in (1) $2 \times$ SSC for $20 \mathrm{~min}$, twice, at room temperature; (2) $50 \%$ formamide in $2 \times$ SSC for $40 \mathrm{~min}$ at $52^{\circ} \mathrm{C}$; (3) RNase $(100 \mu \mathrm{g} / \mathrm{ml}$ in $2 \times \mathrm{SSC})$ for $30 \mathrm{~min}$ at $37^{\circ} \mathrm{C}$; and (4) $0.05 \%$ Triton $\mathrm{X}-100$ in $2 \times \mathrm{SSC}$ overnight at room temperature. Sections were dehydrated in graded alcohols containing $300 \mathrm{~mm}$ ammonium acetate, cleared in xylene, and exposed to $\mathrm{x}$-ray film for $4 \mathrm{~d}$ (ChAT) or $7 \mathrm{~d}$ (TrkA). Slides were then dipped with NTB-3 emulsion (Eastman Kodak, Rochester, NY) (diluted 1:1 with $300 \mathrm{~mm}$ ammonium acetate) and exposed at $4^{\circ} \mathrm{C}$ for $8 \mathrm{~d}$ (ChAT) or $15 \mathrm{~d}$ (TrkA) and developed. In the developmental studies, sections from each age were hybridized under identical conditions with the same probe and were also washed under identical conditions. For NGF treatment studies, sections from NGF-treated, vehicle-treated and untreated animals were hybridized and washed identically.

ISHH data was analyzed by counting silver grains (pixels) over individual cells in the medial septal nucleus (MSN) using an MCID Image Analysis System (Imaging Research Inc., Ontario, Canada) under epifluorescence illumination at $400 \times$ magnification, essentially as described (Holtzman et al., 1992a). Two to four sections at the same anatomical location were chosen for quantitation for each animal and every positive cell was examined. Grain (pixel) counts were measured using a circle size large enough to surround the cell body of magnocellular neurons in the MSN. Only cells dorsal to a line drawn between the center of the anterior commissure were examined. Background measurements were made over the cortex for each slide. Comparing sense and antisense probes, the signal from cortex was indistinguishable. For developing animals, all values were normalized to the average number of grains per cell in the adult tissue processed at the same time. For each NGF- or vehicle-treated animal, the average number of grains per cell was expressed as a percentage of the average value in an untreated animal. Student's $t$ test was used for statistical analysis.

Northern blot analysis. Rat brains were dissected and the septums separated and frozen on dry ice as described (Mobley et al., 1986). Six to twelve septums were pooled. Total RNA was prepared as described
(Chirgwin et al., 1979). Either 20 or $40 \mu \mathrm{g}$ of total RNA was loaded into each well and electrophoresed in $1 \%$ agarose/formaldehyde gels, then blotted to nylon membranes (Genescreen, Dupont/New England Nuclear). RNA was immobilized using UV irradiation, and hybridized with ${ }^{32} \mathrm{P}$ labeled cDNA probes (Holtzman et al., 1992a) for either mouse TrkA (434 bp mouse cDNA), rat ChAT ( 2.3 kb rat cDNA), rat TrkB (483 bp rat cDNA, gift of L. Parada, NCI-Frederick Cancer Research Center), or 18S rRNA (1.1 kb mouse cDNA; Bowman et al., 1981). Hybridization and posthybridization washes were performed as described (Holtzman et al., 1992a). Blots were exposed to a storage phosphate screen (Molecular Dynamics Inc., Sunnyvale, CA) and data digitized by scanning the phosphate screen on a PhosphorImager (Molecular Dynanics Inc.). Data was analyzed on a PC computer using IMAGEQUANT (Molecular Dynamics Inc.). The blots were then exposed to X-ray film (XAR5; Eastman Kodak Company, Rochester, NY). Autoradiograms were quantitated using densitometry and the MCID Image Analysis System.

Immunoprecipitation and immunoblotting. Rat septum and hippocampus were dissected as above (Mobley et al., 1986). In ice cold lysis buffer $(20 \mathrm{~mm}$ Tris pH 7.4, $150 \mathrm{~mm} \mathrm{NaCl}, 10 \%$ glycerol, $1 \%$ NP40, 4 mM sodium orthovanadate, $2 \mathrm{mM}$ PMSF, $1 \mu \mathrm{g} / \mathrm{ml}$ leupeptin, $10 \mu \mathrm{g} / \mathrm{ml}$. aprotinin), the tissues of 6 adults or 8-12 developing subjects were lysed with five strokes in a ground glass $2 \mathrm{ml}$ Dounce homogenizer. Lysates were incubated for $20-30 \mathrm{~min}$ at $4^{\circ} \mathrm{C}$ followed by contrifugation for $10 \mathrm{~min}$ at $12,000 \times \mathrm{g}$. Supernatants $(1.0 \mathrm{ml}$ containing $2.8 \mathrm{mg}$ total protein; BCA, Pierce, Rockford, IL) were immunoprecipitated overnight at $4^{\circ} \mathrm{C}$ with rabbit anti-trk antiserum $1088(12 \mu \mathrm{l})$. The latter was prepared by immunizing with a peptide corresponding to the C-terminus of human TrkA and has been characterized previously (Zhou et al., 1994). Immunoprecipitates were collected with Protein A Sepharose, washed three times with lysis buffer and once with water, redissolved in SDS-PAGE treatment buffer, and subjected to SDS-PAGE in 7.5\% acrylamide gels. Protein was then transferred to nitrocellulose membranes (Hoefer Scientific Instruments, San Francisco, CA) by electroblotting (Holtzman et al., 1992b). After blotting, membranes were probed with a rabbit polyclonal anti-trk A antibody (RTA) that was generated against the extracellular domain of recombinant, baculovirus-expressed rat TrkA and is specific for TrkA (Clary et al., 1994). The blot was incubated with the antibody diluted $1: 10,000$ in TBST $(20 \mathrm{~mm}$ Tris pH $7.4,150 \mathrm{mM} \mathrm{NaCl}, 0.2 \%$ Tween-20) overnight at $4^{\circ} \mathrm{C}$, washed three times over $25 \mathrm{~min}$ in TBST, and then incubated with a horseradish peroxidase labeled anti-rabbit antibody (Amersham, Arlington Heights, IL) diluted 1:10,000 in TBST. Immunoreactive bands were visualized via enhanced chemiluminescence (ECL, Amersham). Films were quantitated using the MCID Image Analysis System.

Trk tyrosine phosphorylation. For Trk tyrosine phosphorylation analysis in vivo, artificial CSF $(4 \mu \mathrm{l})$ or various amounts of mouse NGF in the same volume of artificial CSF was injected into the anterior horn of the right lateral ventricle. Mouse NGF was prepared by ion exchange chromatography as described (Mobley et al., 1986). Either $30 \mathrm{~min}$ or $2 \mathrm{hr}$ after injection the brain was rapidly removed and placed on a cold plate with ventral side up. Two transverse cuts were made. One was at the level of the anterior tip of the olfactory tubercle and the other was rostral to the optic chiasm at the level of the postcommissural fornix. The entire septal region including the vertical limb of the diagonal band, the medial component of the horizontal limb of the diagonal band, and a portion of the nucleus accumbens was separated by removing the overlying corpus callosum and cortex and by making vertical cuts from the floor of the lateral ventricles to the base of the brain, discarding the tissue lateral to the cut on each side. The septal tissue was then frozen on dry ice and stored at $-70^{\circ} \mathrm{C}$ until homogenized in lysis buffer as described above. The tissues of two neonates and one or two adults were pooled for each sample. The volume of the supernatant was adjusted to equalize total protein concentration. Trk proteins were immunoprecipitated from $1 \mathrm{ml}$ with 4 $\mu 1$ of a pan-trk antiserum $(\alpha 203$, Hempstead et al., 1992) overnight at $4^{\circ} \mathrm{C}$. Immunoprecipitates were collected with Protein A Sepharose. Western blotting was performed as described above (Hempstead et al., 1992). Membranes were probed overnight at $4^{\circ} \mathrm{C}$ with a mouse monoclonal anti-phosphotyrosine antibody 4G10 (from D. Morrison, NCIFCRDC) in TBST, washed and then incubated with a horseradish peroxidase labeled anti-mouse antibody (Boehringer Mannheim, Indianapolis, IN) diluted 1:20,000 in TBST. To estimate TrkA protein levels, blots were reprobed with rabbit anti-TrkAout, an antibody to amino acids $102-122$ in the extracellular domain of human TrkA. This 
antibody recognizes TrkA and not TrkB or TrkC (D. Kaplan, unpublished observations). Immunoreactive bands were visualized with enhanced chemiluminescence.

For hippocampus, Trk tyrosine phosphorylation was induced by mixing freshly dissected and triturated tissue with mouse NGF. Tissue from six animals was triturated 20 times in Hank's balanced salt solution (HRSS) with a fire-polished Pasteur pipette, producing individual cells or cell clusters. The triturate was incubated with NGF $(100 \mathrm{ng} / \mathrm{ml})$ in HBSS for $5 \mathrm{~min}$ at $37^{\circ} \mathrm{C}$. The triturates were then washed in cold phosphate buffered saline (PBS) followed by TBS (20 mM Tris, $\mathrm{pH} 7.4,150$ $\mathrm{mm} \mathrm{NaCl}$ ), homogenized in lysis buffer for $30 \mathrm{~min}$, and, after immunoprecipitation with 1088 , assayed for phosphotyrosine content by Western blotting, probing with 4G10 diluted 1:2000, as described above.

Immunocytochemistry. Animals were perfused with $4 \%$ paraformaldehyde in $0.1 \mathrm{M}$ phosphate buffer $(\mathrm{pH} 7.4)$. Brains were postfixed in the same solution for $20 \mathrm{hr}$ at $4^{\circ} \mathrm{C}$ and then equilibrated $48 \mathrm{hr}$ in $20 \%$ sucrose in the same buffer at $4^{\circ} \mathrm{C}$. Coronal sections $(50 \mu \mathrm{m})$ were cut on a freezing-sliding microtome and sections were collected in TBS Sections were treated first with $10 \%$ normal goat serum in TBS containing $0.3 \%$ Triton $\mathrm{X}-100$ for $1 \mathrm{hr}$ at room temperature and then incubated in rabbit anti-TrkA antibody (RTA, 1:4000) in TBST overnight at $4^{\circ} \mathrm{C}$. This was followed by washing three times for 5 min each in TBS and then incubating with a biotin-conjugated goat anti-rabbit antibody (1:800) (Vector Laboratories, Burlingame, CA) in TBST for 1 hr at room temperature. After another wash, sections were incubated with avidin-biotin-peroxidase complex (Vector Laboratories) (1:1000 in TBS) for $1 \mathrm{hr}$ at room temperature. After a final wash, sections were developed by treating with $0.05 \% 3,3^{\prime}$-diaminobenzidine and $0.01 \%$ $\mathrm{H}_{2} \mathrm{O}_{2}$ for $10 \mathrm{~min}$ in TBS. Sections from animals at each of several ages were processed identically, as were sections from animals treated with NGF, vehicle, or untreated.

Cell size was measured using the MCID image analysis system under bright-field illumination at $400 \times$ magnification. For each animal, two to four sections including the MSN were analyzed. All TrkA-positive cells were examined in each section chosen. Only immunoreactive cells with a nucleus in the plane of sections and dorsal to a line draw between the center of the anterior commissure were measured. The area (mean \pm SEM) of all measured cells was calculated. Student's $t$ test was used for statistical analysis. The number of immunostained cells was counted in two sections through the MSN in two animals at each of several ages.

NGF administration. For studies of TrkA and ChAT gene expression, neonatal rats of both sexes were injected intraventricularly with $10 \mu \mathrm{l}$ of PBS containing NGF $(30 \mu \mathrm{g})$ or the vehicle control, as described (Mobley et al., 1986). Animals were sacrificed at PD7. In the experiments that evaluated the effect of multiple intraventricular NGF injections on Trk phosphorylation, NGF $(30 \mu \mathrm{g})$ or PBS vehicle was injected on PD5 and -7 and the animals were sacrificed on PD9.

Characterization and administration of NGF antibodies. GAM is an antiserum produced in goats to mouse NGF prepared by ion exchange chromatography, followed by gel filtration on Sephadex G75, as described (Mobley et al., 1986). It is specific for NGF (Crutcher et al., 1993; see below). The potency of GAM and specificity was assayed in vitro. In cultures of chick embryonic DRG neurons (Longo et al., 1990) the activity of neurotrophins was tested at their ED80 (i.e., concentration at which $80 \%$ of maximum neurite outgrowth was elicited; mouse NGF $=100 \mathrm{pg} / \mathrm{ml} ; \mathrm{BDNF}=50 \mathrm{pg} / \mathrm{ml}$; NT-3 $=50$ $\mathrm{pg} / \mathrm{ml}$ ) in the absence or presence of a series of GAM or nonimmune goat serum (NGS) dilutions (1:50 to 1:500,000). Plates were coated with laminin $(1 \mu \mathrm{g} / \mathrm{ml})$ for $3 \mathrm{hr}$ prior to assaying the activities of BDNF and NT-3 (recombinant human isoforms, gift of F. Hefti, Genentech, South San Francisco, CA). GAM and NGS were also tested in primary cultures of fetal rat basal forebrain prepared from E15 rat embryos, as previously described (Knüsel et al., 1990). Cultures were maintained in modified L-15 medium supplemented with $5 \%$ heatinactivated horse serum and $0.5 \%$ heat-inactivated FCS. They were grown for $5 \mathrm{~d}$ and treated with neurotrophins in the presence or absence of GAM or NGS for an additional $3 \mathrm{~d}$. For these cultures, recombinant human NGF was used (Genentech). GAM or NGS were preincubated with neurotrophins for $2 \mathrm{hr}$ at $37^{\circ} \mathrm{C}$ at their final concentrations in complete medium before adding to the cultures. To induce ChAT activity, NGF could be assayed at $300 \mathrm{pg} / \mathrm{ml}$. Higher concentrations of BDNF and NT-3 were required $(20 \mathrm{ng} / \mathrm{ml})$. To enhance NT-3 activity, this neurotrophin was tested in the presence of K252b
(Knusel et al., 1992). At the end of the treatment, the cultures were taken for biochemical determination of ChAT activity using the procedure of Fonnum (1975).

For in vivo antiserum injections, GAM $(500 \mu \mathrm{g}$ total protein $/ 5 \mu \mathrm{l})$ was injected into the lateral ventricle at PD 3, 4, 6, 8, and 10 as described (Mobley et al., 1986). Control animals were injected with 500 $\mu \mathrm{g}$ of total protein $/ 5 \mu \mathrm{l}$ of NGS. Animals were sacrificed at PD 11. Injection of either GAM or NGS produced a degree of hydrocephalus, as evidenced by enlargement of the lateral ventricles. This was quantitated by measuring the size of both lateral ventricles in three or four sections at the level of the septum in each of six GAM and six NGS treated animals. There was no significant difference between GAM(mean \pm SEM $; 11.8 \pm 1.31 \mathrm{~mm}^{2}$ ) and NGS-injected subjects (mean \pm SEM; $\left.9.7 \pm 2.0 \mathrm{~mm}^{2}\right)(p=0.38$; Student's $t$ test $)$.

To evaluate the distribution of infused antibodies, the brains of rats that were injected with GAM, NGS, or PBS were examined following sacrifice just prior to the injection scheduled for PD8. Untreated brains were also taken. Frozen sections $(40 \mu \mathrm{m})$ were collected in TBS. Sections were preblocked with 5\% normal rabbit serum (NRS) in TBST for $30 \mathrm{~min}$ at room temperature, washed in TBS, and incubated with biotinylated rabbit anti-goat IgG (1:1000) (Vector Laboratories) in TBST for $2 \mathrm{hr}$ at room temperature. The sections were washed and incubated with avidin-biotin-peroxidase complex (1:1000) (Vector laboratories) in TBS. Color development was carried out for $30 \mathrm{~min}$ as above.

To evaluate the tissue level of antibodies to NGF, we developed an ELISA technique similar to that used previously (Mobley et al., 1989). Nunc MaxiSorp plates (Nunc; Applied Scientific, South San Francisco, CA) were coated with $100 \mathrm{ng}$ of mouse NGF per $100 \mu \mathrm{l}$ coating buffer per well (Weskamp and Otten, 1987) overnight at $4^{\circ} \mathrm{C}$. Plates were then washed three times in $0.05 \%$ Tween 20 in $10 \mathrm{~mm}$ PBS and blocked with $200 \mu \mathrm{l}$ of $5 \%$ FCS in $10 \mathrm{~mm}$ PBS for $2 \mathrm{hr}$ at room temperature. GAM and NGS standards were prepared by serial dilution with sample buffer (Mobley et al., 1989) from 1:20,000 to $1: 4 \times 10^{7}$. One hundred microliters was placed into each well. Tissue samples were prepared by diluting 1 part tissue to 9 parts sample buffer. Samples were sonicated for $30 \mathrm{sec}$ at $4^{\circ} \mathrm{C}$, centrifuged at $5000 \times \mathrm{g}$ for $20 \mathrm{~min}$, and $100 \mu \mathrm{l}$ of the supernatant placed into each well. Incubation was carried out overnight at $4^{\circ} \mathrm{C}$ on a shaker. The plates were then washed and incubated overnight at $4^{\circ} \mathrm{C}$ with $100 \mu \mathrm{l}$ per well of biotinylated rabbit anti-goat IgG (1:1000; Vector Laboratories) in $10 \mathrm{~mm}$ PBS containing $1 \%$ FCS. After washing, $100 \mu \mathrm{l}$ of Streptavidin-horseradish peroxidase (1:2000) (Zymed, South San Francisco) in 10 mM PBS with $1 \%$ FCS was placed in each well and left on the shaker at room temperature for $2 \mathrm{hr}$. Color was developed, as indicated (Mobley et al., 1989). The standard curve was the difference in OD492 between GAM and NGS at each dilution. For tissue samples, the value plotted was the OD492 for GAM-treated subjects minus the value for the NGS-treated subjects. The final dilution of GAM in the tissue was calculated by adjusting for the addition of sample buffer prior to sonication.

\section{Results}

TrkA and ChAT MRNA were present in developing basal forebrain neurons

NGF signals through TrkA (Kaplan et al., 1991a,b; Klein et al., 1991; Meakin and Shooter, 1991a,b). Robust, dose-dependent, stereospecific NGF actions on developing BFCNs (Gnahn et al,, 1983; Mobley et al., 1986, 1988; Johnston et al., 1987) predicted that $\operatorname{Trk} A$ and $C h A T$ expression would be colocalized in these cells. To examine gene expression, ISHH was performed on sections through the septal (basal forebrain) region of $\mathrm{PD} 11$ rats with ${ }^{35} \mathrm{~S}$ labeled antisense RNA probes. Dense clusters of silver grains for TrkA and ChAT mRNA were scen in identical distributions, overlying magnocellular neurons in the MSN and vertical limb of the diagonal band (Fig. $1 A, B$ ). No specific signal was detected using sense probes (data not shown). The thickness of the sections used prevented a complete serial section analysis to prove colocalization of TrkA and ChAT mRNA. Nevertheless, adjacent sections in which the first was hybridized for TrkA mRNA and the second for ChAT mRNA were available for examination. The diameter of TrkA-positive neurons at PD11 is 
TrkA
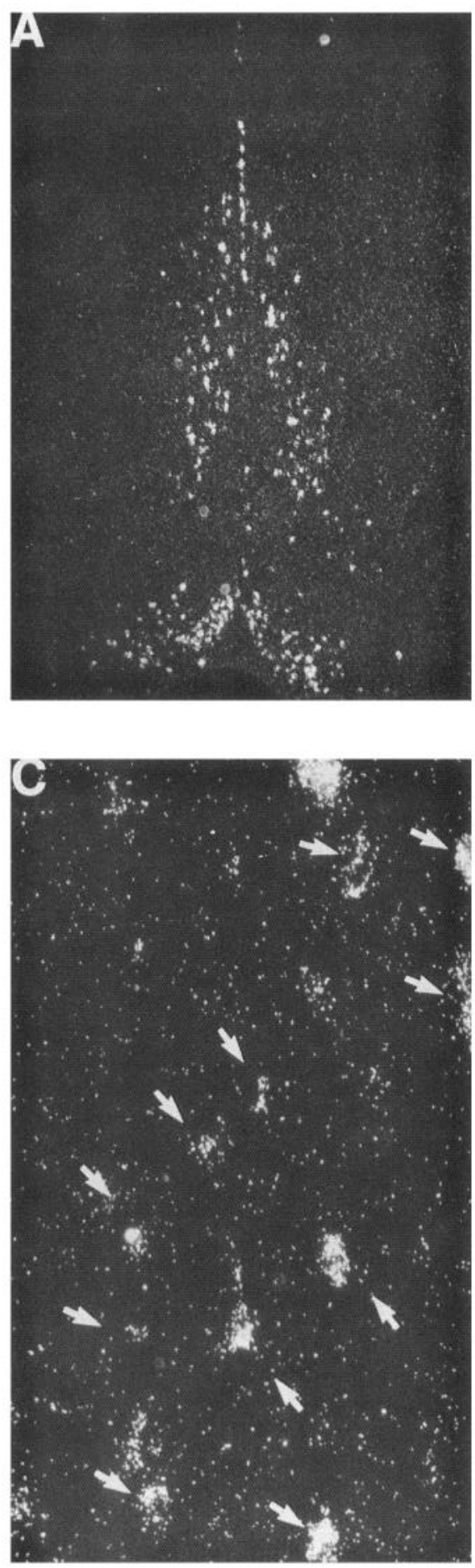

ChAT
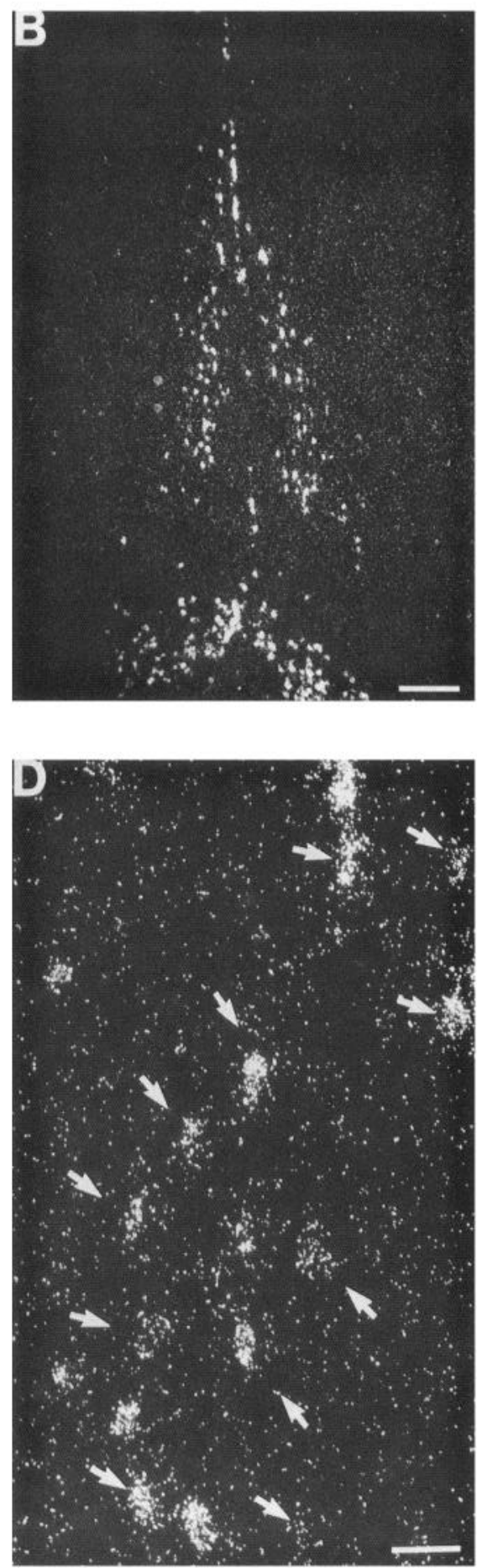

Figure 1. Codistribution of TrkA and ChAT mRNA in the rat septum using ISHH. $A$, A low-power dark-field photomicrograph shows PD11 septum hybridized with the TrkA antisense riboprobe. $B$, The adjacent section was hybridized with the ChAT antisense riboprobe. $A$ and $B$ are shown at higher power in $C$ and $D$, respectively. In $C$ and $D$ is shown a field in which several individual cells hybridized with probes for both TrkA mRNA (white arrows in $C$ ) and ChAT mRNA (white arrows in $D$ ). Scale bars: $A$ and $B, 300 \mu \mathrm{m} ; C$ and $D, 50 \mu \mathrm{m}$. approximately $14 \mu \mathrm{m}$ (see below); therefore, using $18 \mu \mathrm{m}$ sections, we would expect some cells to be present in both sections. In high power photomicrographs, it was possible to demonstrate that some individual cells contained both ChAT and TrkA mRNA (Fig. 1C,D). The distribution of TrkA and ChAT mRNAs in basal forebrain neurons suggest that, as for adult subjects (Holtzman et al, 1992a), the gene for TrkA is expressed in developing BFCNs.
TrkA and ChAT gene expression were developmentally regulated

Earlier studies have suggested that endogenous NGF regulates the differentiation of BFCNs (Large et al., 1986; Auberger et al., 1987; Vantini et al., 1989). If so, TrkA should be expressed throughout development. To address this point, ISHH was used to detect TrkA and ChAT mRNA in the basal forebrain at embryonic day (ED) 17, at PD 0, 4, 7, 11, 21, 30, and in the adult. 


\section{PD 4}
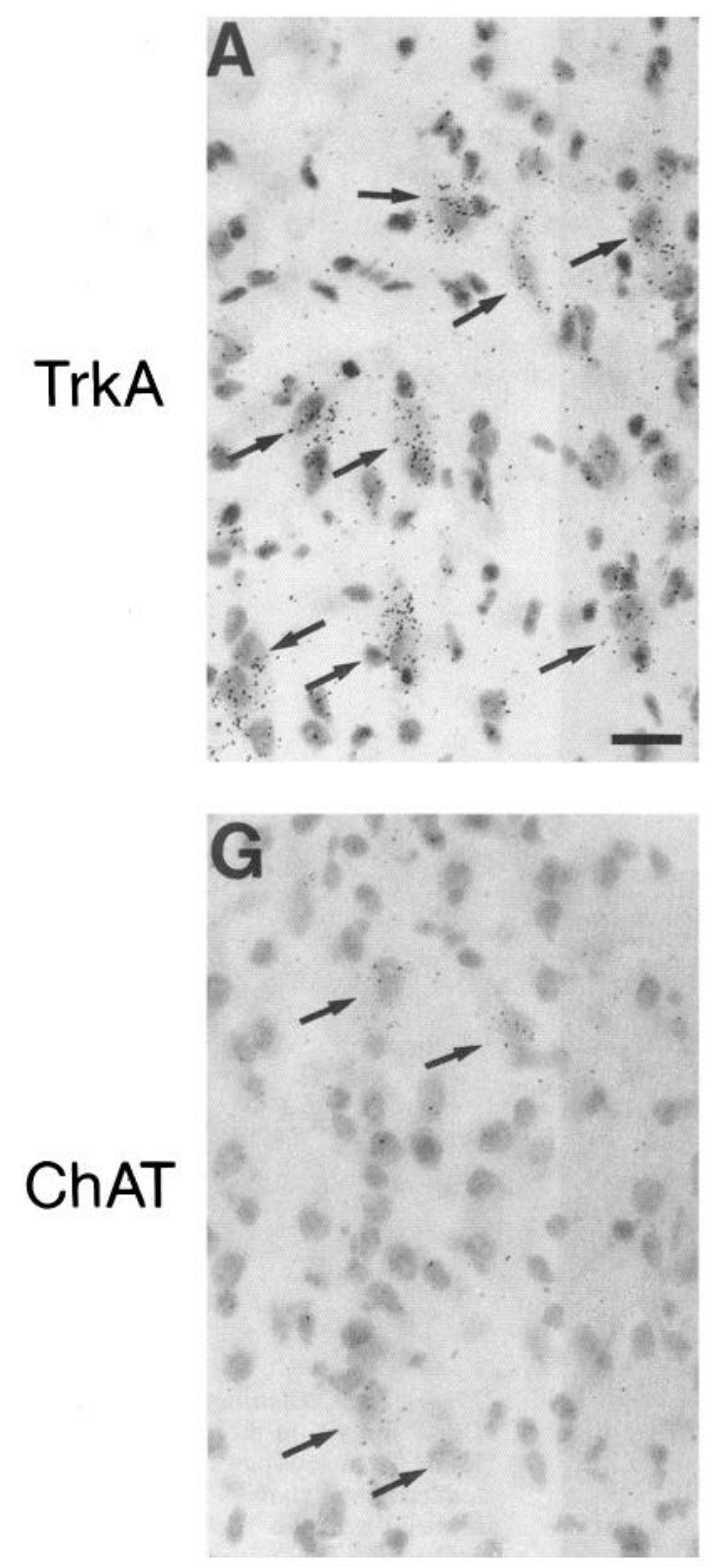

PD 7
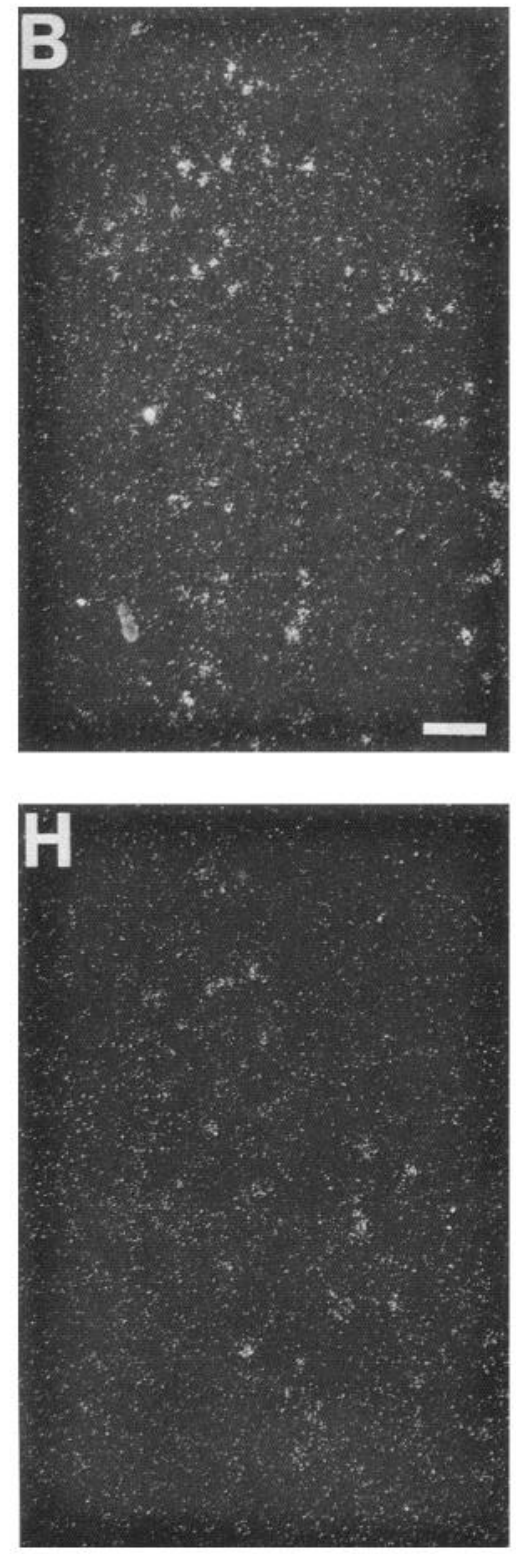

PD 11
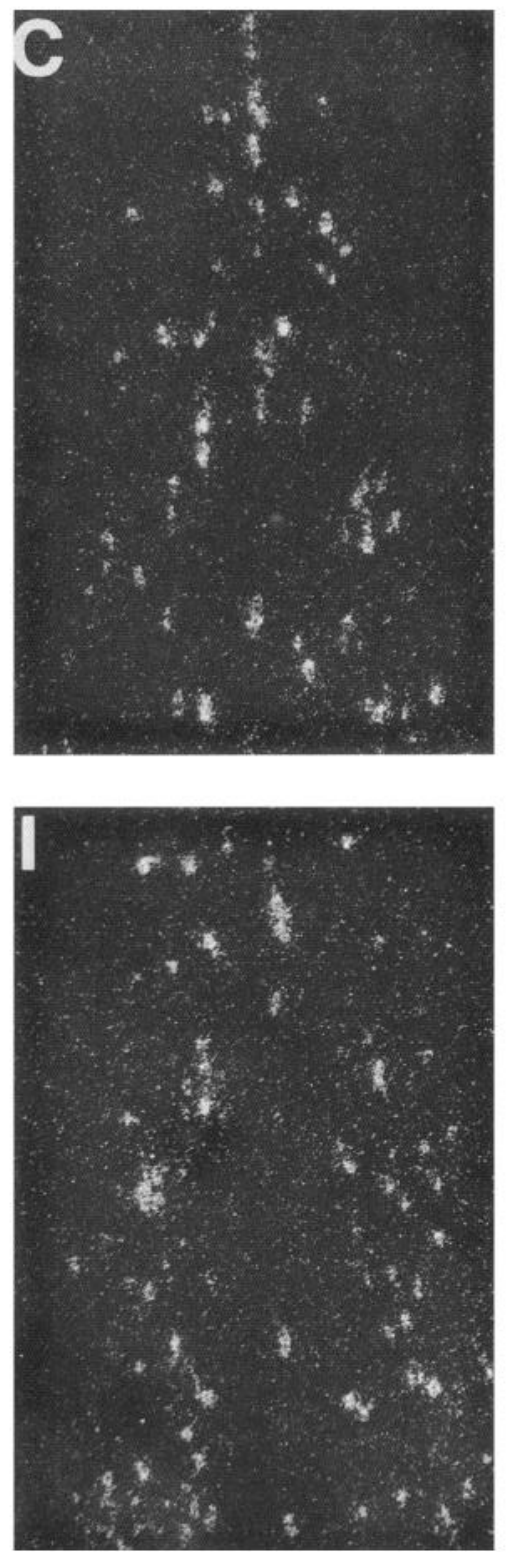

Figure 2. TrkA and ChAT mRNA in the developing septum. Photomicrographs of the septum showing TrkA $(A-F)$ and ChAT $(G-L)$ mRNA by ISHH. $A$ and $G$, PD 4, high-power bright-field photomicrographs showing cells containing either TrkA mRNA or ChAT mRNA (arrows). All other panels are low-power dark-field photomicrographs. $B$ and $H$, PD7; $C$ and $I$, PD11; $D$ and $J$, PD21; $E$ and $K$, PD30; $F$ and $L$, adult (2 month old). Scale bars: $A$ and $G, 20 \mu \mathrm{m} ; B-F$ and $H-L, 100 \mu \mathrm{m}$.

At E17, neither TrkA nor ChAT expression was detected. By PD0, however, grain clusters were found over a few cells; this was true using either probe. Figure 2 shows representative sections of basal forebrain at ages from PD4 to adulthood hybridized for either TrkA mRNA $(A-F)$ or ChAT mRNA $(G-L)$. TrkA and ChAT mRNA were present at relatively low levels at PD4. Labeled cells were neurons, as demonstrated by their relatively large cell body and large nucleus (Fig. 2A,G). A dramatic increase in labeling for both TrkA and ChAT was apparent at PD11. The signal was still prominent at PD21 and declined by PD30. The distribution of labeled cells was the same for ChAT and TrkA at all ages. These data were quan- titated by counting grains (pixels) over neurons in the MSN (Fig. 3). Note the marked increase in gene expression for both TrkA and ChAT from PD4 to PD11. For TrkA mRNA, the increase was 3-fold and for ChAT it was 3.4-fold. By ISHH, both TrkA and ChAT mRNA were decreased in the adult. By visual inspection, grain development in autoradiograms of the MSN agreed with the developmental pattern for grain count over individual cells (Fig. 3). The number of TrkA and ChAT mRNA positive cells increased during early postnatal development, and then decreased in the adult. In sections through the anterior portion of the MSN, the number of TrkA mRNApositive cells per section was counted in subjects at PD7, PD21 


\section{PD 21}
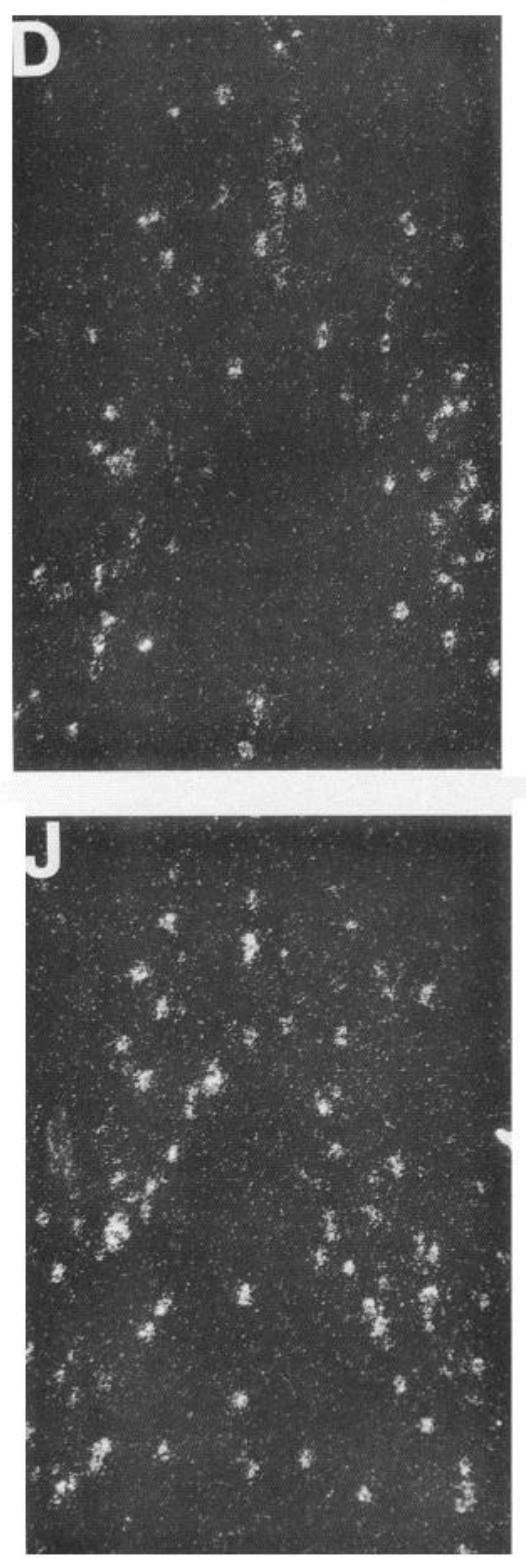

\section{PD 30}
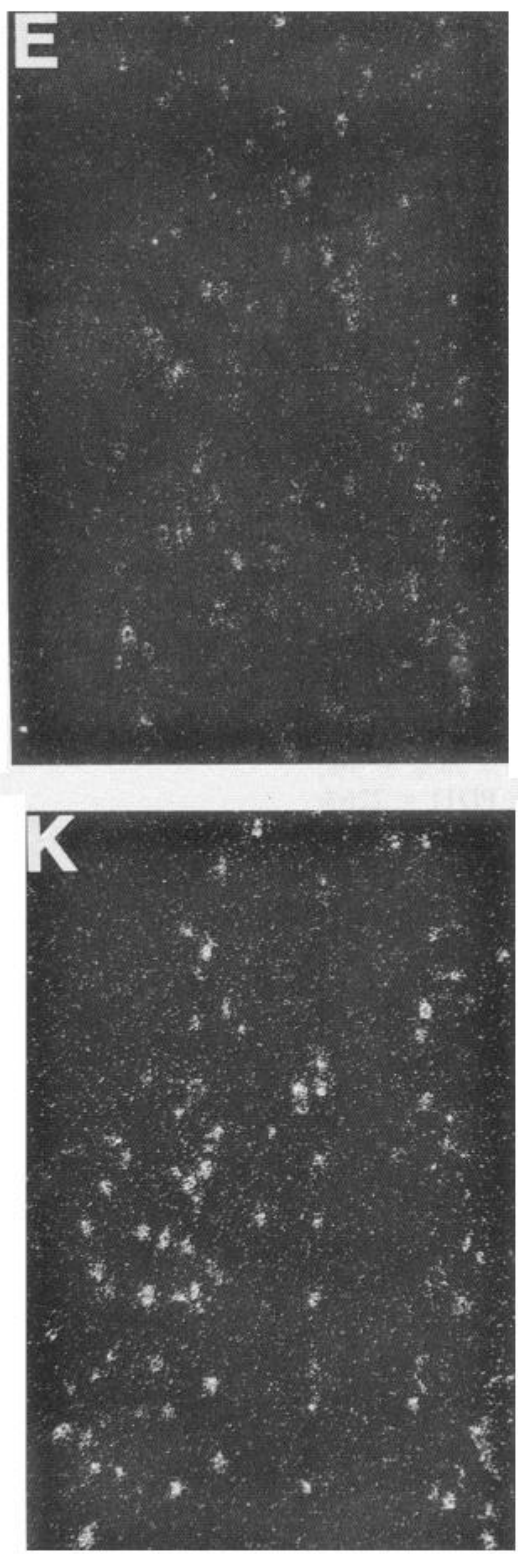

\section{Adult}
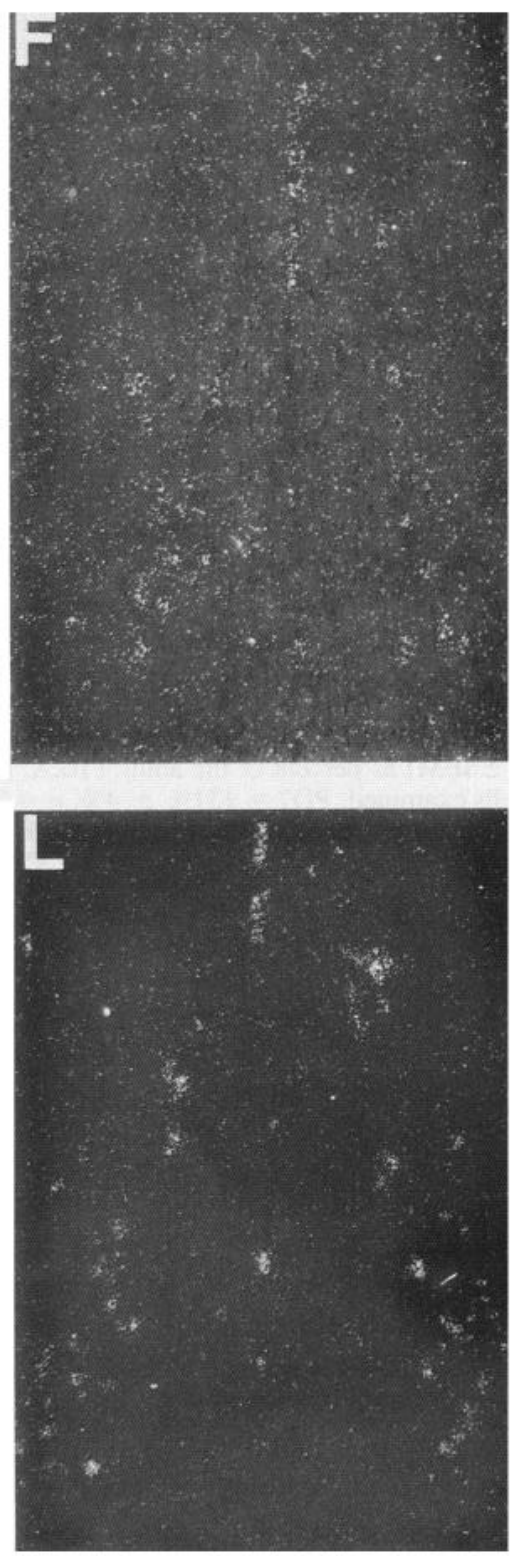

Figure 2. Continued.

and in the adult. The number (mean \pm SEM) in the adult was $47 \pm 4$. At PD7 there was $53 \pm 9 \%$ of the adult number; at PD21 there was $166 \pm 36 \%$.

Northern blots were also used to quantitate TrkA and ChAT mRNA levels during development. Total RNA from PD4, PD11, PD21, and adult animals were blotted and hybridized with 32P labeled cDNA probes for TrkA mRNA and ChAT mRNA. At PD4, both TrkA and ChAT mRNA were present at relatively low levels. There were marked and proportional increase for both mRNAs between PD4 and PD11 and between PD11 and PD21. The levels at PD21 were comparable to those in the adult. Northern blots were quantitated using either a PhosphorImager or densitometry of autoradiograms. A probe for $18 \mathrm{~S}$ ribosomal RNA was used to control for RNA loading.
Figure $4 B$ gives the results from four experiments. At PD4, TrkA mRNA was $19 \%$ of the adult level. The level more than doubled at PD11 (44\%), and by PD21 was nearly equal to the adult $(93 \%)$. The expression of ChAT followed a very similar pattern. ChAT mRNA increased from 9\% at PD4 to $31 \%$ at PD11, and reached adult levels at PD21. Thus, ISHH and Northern blot analysis indicated that TrkA was expressed throughout the postnatal period in a pattern closely paralleling that for ChAT. Of note, the developmental patterns determined by ISHH and Northern blots differed. While both methods documented increased mRNA levels in the early postnatal period, by ISHH the levels plateaued between PD11 and PD21, and fell between PD21 and the adult. The Northern blots showed increases from PD11 to 21 and maintenance of relatively high 


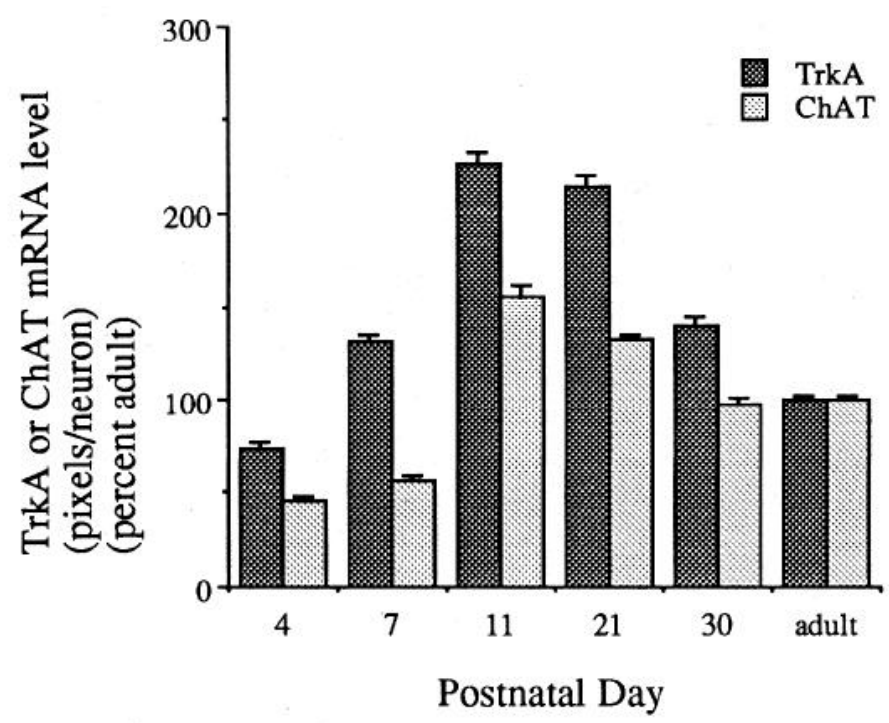

Figure 3. Quantitation of in situ hybridization data for TrkA and ChAT mRNA in the MSN. The number of grains (pixels) per cell was counted; data were collected from three to five animals at each developmental age and normalized to the average level in the adult. Values are mean $( \pm$ SEM) as percent of the adult. (TrkA: PD4 $=74 \% \pm 3 \%$, $n=193$ cells examined; PD7 $=131 \% \pm 4 \%, n=230 ;$ PD1 $1=226 \%$ $\pm 7 \%, n=370 ; \mathrm{PD} 21=215 \% \pm 6 \%, n=399 ; \mathrm{PD} 30=141 \% \pm$ $4 \%, n=279 ;$ Adult $=100 \% \pm 2 \%, n=383$. ChAT: PD4 $=46 \% \pm$ $2 \%, n=199 ; \mathrm{PD} 7=57 \% \pm 2 \%, n=291 ; \mathrm{PD} 11=156 \% \pm 6 \%, n$ $=352 ; \mathrm{PD} 21=132 \% \pm 3 \%, n=350 ; \mathrm{PD} 30=98 \% \pm 3 \%, n=$ 299 ; Adult $=100 \% \pm 2 \%, n=328$ ).

levels in the adult. The source of this discrepancy is unclear, but may have been due to restricted access of the probes for TrkA and ChAT mRNA in more mature neurons in ISHH studies, as discussed below.

\section{Trk A protein was present in the developing septum and hippocampus}

For TrkA expression to serve NGF signaling, the TrkA protein must be produced and be present at the cell surface to bind and be activated by NGF. Using an antiserum specific to TrkA (RTA), we examined the distribution and relative level of TrkA protein during development. Immunostained neuronal profiles were seen in the rat basal forebrain throughout the postnatal period. Figure 5 shows representative sections from animals at PD0, 4, 11,21, and the adult. The distribution of immunostained cells conformed to that seen by ISHH. Immunostaining was present at PD0 (Fig. 5A,G). The intensity of immunostaining increased markedly from PD0 through PD21. Densely stained fibers were also present at PD21 (Fig. $5 J$ ). The intensity of fiber staining was even greater in the adult (Fig. $5 K$ ). TrkA immunopositive fibers were clearly seen in the hippocampus of adult subjects (Fig. $5 F, L$ ). Fibers were numerous in the hilus of the dentate gyrus (Fig. $5 F, L$ ). An occasional fiber exited the hilus to run in the inner aspect of the molecular layer. Thus, TrkApositive fibers were present in hippocampal regions known to be innervated by septal neurons (Swanson et al., 1987). The number of stained fibers was much greater in the posterior hippocampus. Fibers were also seen in around CA3 pyramidal cells. The number of immunopositive neuron cell bodies was also influenced by development. The number of TrkA-positive cells in sections through the anterior MSN averaged 82 per section at
A.
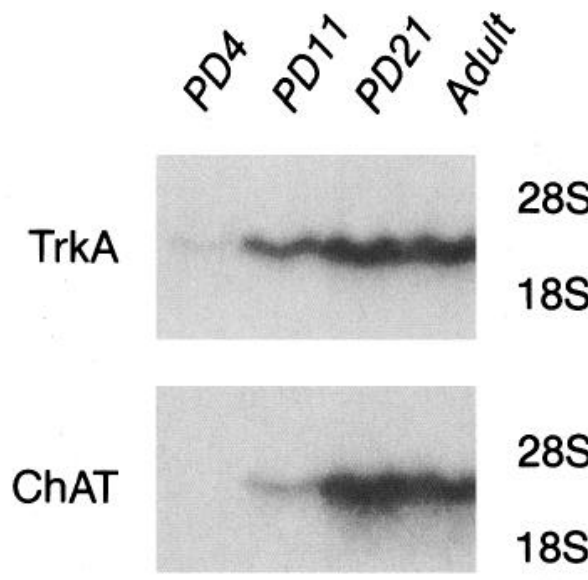

$28 S$

$18 S$

\section{8srRNA}

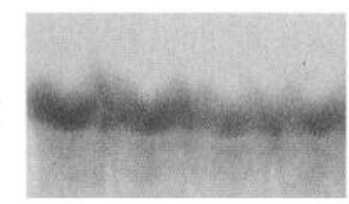

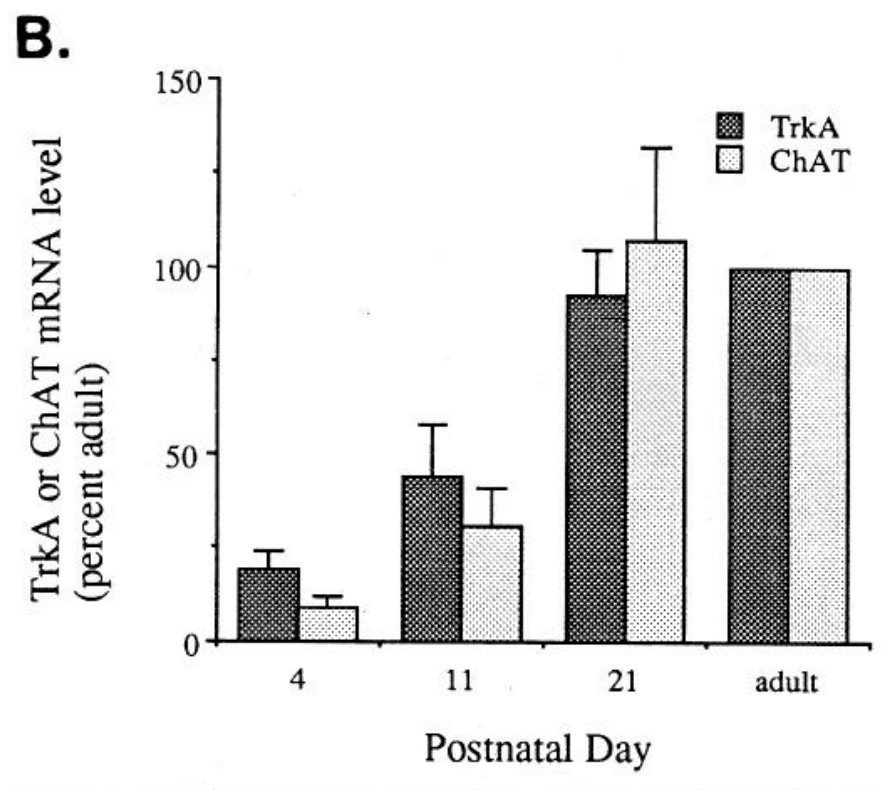

Figure 4. Northern analysis of TrkA and ChAT mRNA levels in the developing septum. $A$, Northern blots of $40 \mu \mathrm{g}$ samples of total RNA from the pooled septums of $6-12$ animals. Blots were hybridized with ${ }^{32} \mathrm{P}$ labeled TrkA cDNA probe, stripped, and rehybridized with the ChAT probe. Blots were finally reprobed with the 18S rRNA probe to control for RNA loading. $B$, Quantitation of TrkA and ChAT mRNA levels. Four experiments were carried out. The data are given as percentage of the average adult level (mean \pm SEM). TrkA: PD4 $=19 \%$ $\pm 5 \% ; \mathrm{PD} 11=44 \% \pm 14 \% ; \mathrm{PD} 21=93 \% \pm 10 \%$, adult $=100 \%$. ChAT: PD4 $=9 \% \pm 3 \% ;$ PD $11=31 \% \pm 10 \%$; PD21 $=107 \% \pm$ $25 \%$; adult $=100 \%$. 
PD4, 182 at PD21, and 119 in the adult ( $n=2$ animals examined at each age).

To quantitate TrkA protein levels, Trk protein was immunoprecipitated from homogenates of septum or hippocampus with a rabbit anti-Trk antiserum (1088). The immunoprecipitate was submitted to $7.5 \%$ SDS-PAGE, transferred to nitrocellulose membranes, and the blots probed with RTA. TrkA protein was present in the septum at PD4 (Fig. 6A). By PD21, the amount increased and, on average, was equal to the adult level. In the hippocampus, TrkA was barely detected at PD4. The amount markedly increased at PD21 and was even greater in the adult. The data are quantitated in Figure $6 B$. Thus, as was true for TrkA mRNA, TrkA protein increased considerably during the first postnatal weeks.

\section{NGF induced tyrosine phosphorylation of TrkA in developing} and mature BFCNs

Activation of TrkA by NGF is marked by tyrosine phosphorylation of this receptor (Kaplan et al., 1991a,b; Klein et al., 1991; Meakin and Shooter, 1991a,b; Jing et al., 1992). To determine whether TrkA in developing BFCNs was activated by NGF, the level of TrkA tyrosine phosphorylation was examined after treating subjects in vivo with exogenous NGF. Experiments were carried out at PD 5, 7, 10, and in adults. NGF (10 ng, $100 \mathrm{ng}$, $1 \mu \mathrm{g}$, or $10 \mu \mathrm{g}$ ) was injected into the anterior horn of the right lateral ventricle. Animals injected with artificial CSF served as vehicle controls. Thirty minutes postinjection, animals were sacrificed, the brains removed, and the septums dissected. Tissue was submitted to immunoprecipitation and blotting as described in Methods. Using this technique, at PD5 there was no apparent increase in TrkA tyrosine phosphorylation (data not shown). By PD7, NGF-mediated TrkA phosphorylation was clearly evident. An injection of $100 \mathrm{ng}$ was effective and induction of phosphorylation was greater with $1 \mu \mathrm{g}$ of NGF; a further increase was seen with $10 \mu \mathrm{g}$ of NGF (Fig. 7A). Similar results were observed with PD10 animals (data not shown). In adults, it appeared that a smaller NGF dose was effective. A small increase in TrkA tyrosine phosphorylation was apparent even at $10 \mathrm{ng}$ and the effect at $100 \mathrm{ng}$ was nearly equivalent to that at $1 \mu \mathrm{g}$ (Fig. 7B).

The effect of NGF treatment on TrkA tyrosine phosphorylation was registered for long periods following injection. In the adult, a single injection of cxogenous NGF $(1 \mu \mathrm{g})$ produced persistent Trk phosphorylation for at least $2 \mathrm{hr}$ (Fig. 7C). NGF injection during early postnatal development also produced prolonged activation of TrkA. Postnatal rats were given intraventricular injections of NGF $(30 \mu \mathrm{g})$ or vehicle on PD5 and PD7 and were sacrificed at PD9. Western blots demonstrated phosphorylation of TrkA in the septum $2 \mathrm{~d}$ after the last NGF injection (Fig. 7D). There was no difference in TrkA protein levels between NGF- and vehicle-treated subjects in these experiments (data not shown). NGF induction of TrkA phosphorylation was not confined to the septum. In other experiments, the hippocampus was freshly dissected, dissociated by trituration and treated with NGF in vitro. Following immunoprecipitation and blotting, induction of tyrosine phosphorylation on TrkA was readily observed (Fig. 7E). This result confirms earlier findings (Knusel et al., 1994).

\section{NGF induced gene expression for TrkA and ChAT}

Two findings suggested that, like ChAT (Gnahn et al., 1983; Mobley et al., 1986, 1988; Caviocchioli et al., 1991) gene ex- pression for TrkA may be regulated by NGF in the developing basal forebrain. The first was data showing that administration of exogenous NGF increased TrkA mRNA levels in the basal forcbrain of adult rats (Holtzman et al., 1992a). The second, demonstrated herein, was the very similar patterns for regulation of expression of these genes. To ask whether $\operatorname{Tr} k A$ was regulated by NGF in neonatal rats, TrkA mRNA levels were measured in animals injected intraventricularly with NGF on PD3 and 5. Animals were sacrificed on PD7. Control littermates received vehicle alone. TrkA and ChAT mRNA levels in the septum were examined by ISHH. Exogenous NGF increased mRNA for both TrkA (Fig. 8A-C) and ChAT (Fig. 8D-F). Quantitation of silver grains over individual cells showed that infusion of NGF produced a modest $(40 \%)$ but significant increase in TrkA mRNA (Fig. 9A). A somewhat greater increase $(67 \%)$ was seen for ChAT mRNA (Fig. 9B). These experiments were repeated using Northern analysis. Intraventricular injections of NGF on PD1, 3 , and 5 consistently resulted in an increase in the TrkA mRNA level measured at PD7 (Fig. 10). However, the increase was small; by PhosphorImager analysis it avcraged $14 \%$. ChAT mRNA levels responded more robustly, showing a $117 \%$ increase (Fig. 10). TrkB mRNA has been localized to medial septal neurons (Merlio et al., 1992). Significantly, we failed to see NGF induction of TrkB mRNA. Taken together, the results from in situ hybridization and Northern blot studies show that exogenous NGF can regulate expression of TrkA and ChAT in neurons of the developing basal forebrain. Failure to induce expression of $\operatorname{TrkB}$ points to specificity in the NGF response.

\section{Anti-NGF antibody infusion decreased expression of TrkA and ChAT}

NGF antibodies have been used to attempt to block the actions of endogenous NGF (Levi-Montalcini and Booker, 1960; Johnson et al., 1980; Goedert et al., 1984; for review, see Longo et al., 1993). In CNS studies, intraventricular administration of anti-NGF antibodies was shown to produce a decrease in $\mathrm{Ch} \Lambda \mathrm{T}$ activity in the basal forebrain of neonatal rats (Vantini et al., 1989). To determine whether endogenous NGF regulated TrkA gene expression, we attempted to achieve significant tissue levels of a potent and specific NGF antiserum.

GAM is a goat antiserum to purified mouse NGF. We tested GAM in the chick DRG assay, measuring the extent to which GAM would block the activities of NGF, BDNF, and NT-3. The neurotrophins were examined at their ED80 for neurite outgrowth; for mouse NGF this was $100 \mathrm{pg} / \mathrm{ml}$ and for BDNF and NT-3 it was $50 \mathrm{pg} / \mathrm{ml}$. GAM, at a dilution of $1: 55,000$, blocked $50 \%$ of the response to NGF. For BDNF and NT-3, the dilution of GAM required was 1:250. NGS had no effect at these dilutions. Therefore, immunoreactivity of GAM for BDNF and NT-3 was only about $0.5 \%$ of that for NGF. The ability of GAM to block NGF actions on BFCNs was also tested in vitro. Using fetal basal forebrain cultures, we found that GAM at 1:32,000 completely blocked NGF ( $300 \mathrm{pg} / \mathrm{ml})$ induction of ChAT activity $[\mathrm{NGF}=170 \pm 10 \%$ of the control $(n=7)$; GAM plus NGF $=100 \pm 6 \%(n=7)(p<0.001)]$. In contrast to the data for NGF, GAM at this dilution had no effect on induction of ChAT by BDNF $(20 \mathrm{ng} / \mathrm{ml})(\mathrm{BDNF}=150 \pm 16 \%, n=4$; $\mathrm{BDNF}$ plus GAM $=160 \pm 17 \% ; n=4$, NS $)$ or NT-3 $(20 \mathrm{ng} / \mathrm{ml}$ plus 30 nм K252b) (NT-3 $=206 \pm 25 \%, n=8$; NT-3 plus GAM $=192 \pm 19 \%, n=8$, NS).

GAM was injected into the lateral ventricles of neonatal rats at PD3, 4, 6, 8, and 10. Control animals were injected with NGS. 


\section{PD 0}
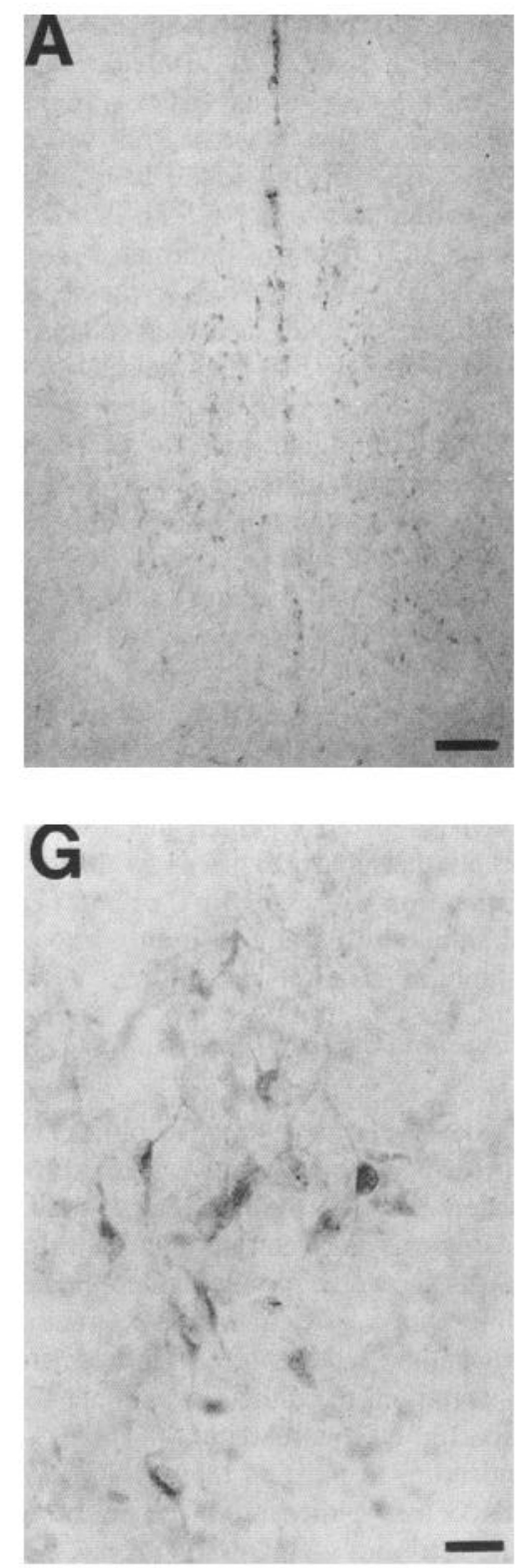

PD 4

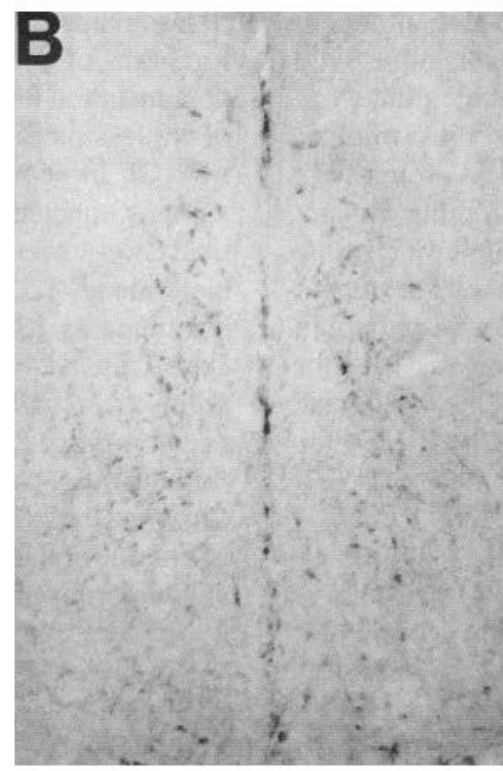

H

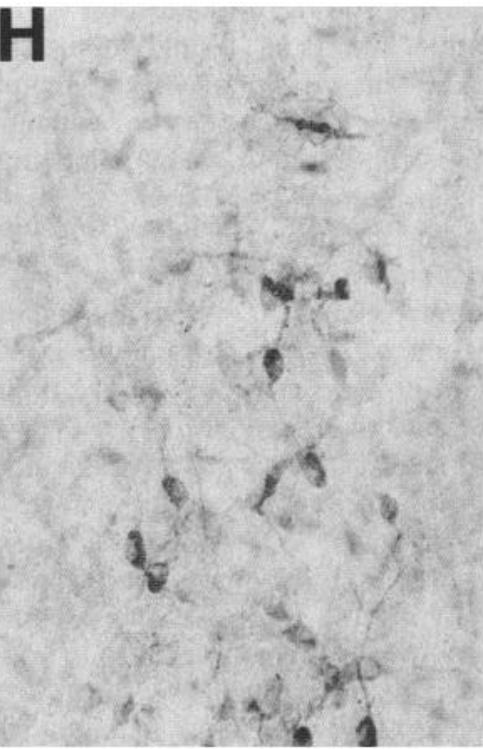

PD 11
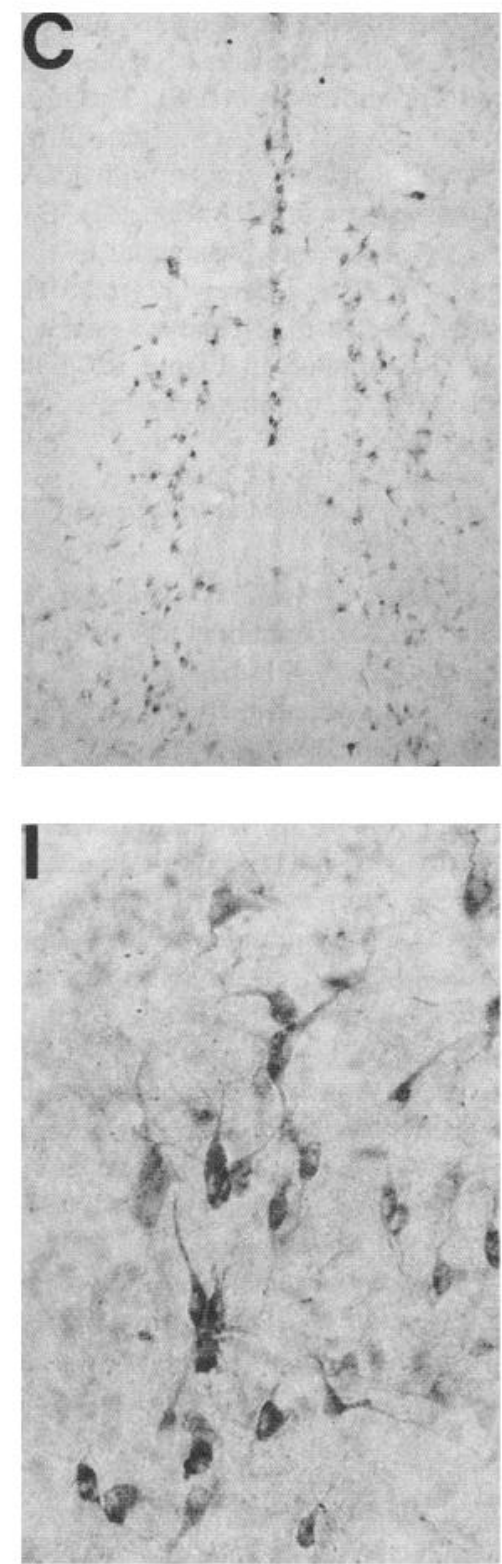

Figure 5. TrkA immunoreactive cells are present during the entire postnatal period. Bright-field photomicrography of TrkA immunoreactive cells. $A-E$, The septum at low-power, and at high-power $(G-K) . A$ and $G, \mathrm{PD} 0 ; B$ and $H, \mathrm{PD} 4 ; C$ and $I, \mathrm{PD} 11 ; D$ and $J, \mathrm{PD} 21 ; E$ and $K$, adult $(2$ months). Low-power $(F)$ and high-power $(L)$ bright-field photomicrographs of a section through the ventral hippocampus in an adult animal showing dense TrkA immunoreactive fibers. Arrows are located in the molecular layer of the dentate gyrus and point to neuron cell bodies in the granule cell layer. $H$, Hilus. Scale bars: $A-F, 100 \mu \mathrm{m} ; G-L, 25 \mu \mathrm{m}$.

We tested the ability of these infusions to deliver antibodies to the brain parenchyma. At PD8, prior to the next scheduled injection, some animals were sacrificed and the distribution and level of antibodies was examined. Using a biotinylated rabbit anti-goat IgG for immunostaining, both GAM and NGS were widely distributed throughout the brain (data not shown). The level of GAM was measured in septum and hippocampus via ELISA. The concentration of antibody in hippocampus was equivalent to a 1:25,000 dilution of GAM. The same concentration was achieved in septum.

At PD8 there is approximately $300 \mathrm{pg}$ NGF/gm tissue in the hippocampus and $220 \mathrm{pg}$ NGF/gm tissue in the septum (Large et al., 1986). The chick DRG assay was used to determine the ability of GAM, at the level achieved in the septum and hippocampus, to block the response to NGF. At a GAM dilution of $1: 25,000$, the actions of NGF $(300 \mathrm{pg} / \mathrm{ml})$ were fully blocked. NGS had no effect at this dilution. At a similar concentration, GAM also blocked the actions of NGF (300 pg/ml) on BFCNs (see above).

Next we examined the effect of GAM on gene expression. Antibody injected animals were sacrificed at PD11 and ChAT and TrkA mRNA were examined by Northern blotting. Figure $11 A$ shows that infusion of GAM resulted in a decrease in ChAT mRNA and TrkA mRNA. Quantitation of data from four exper- 
PD 21
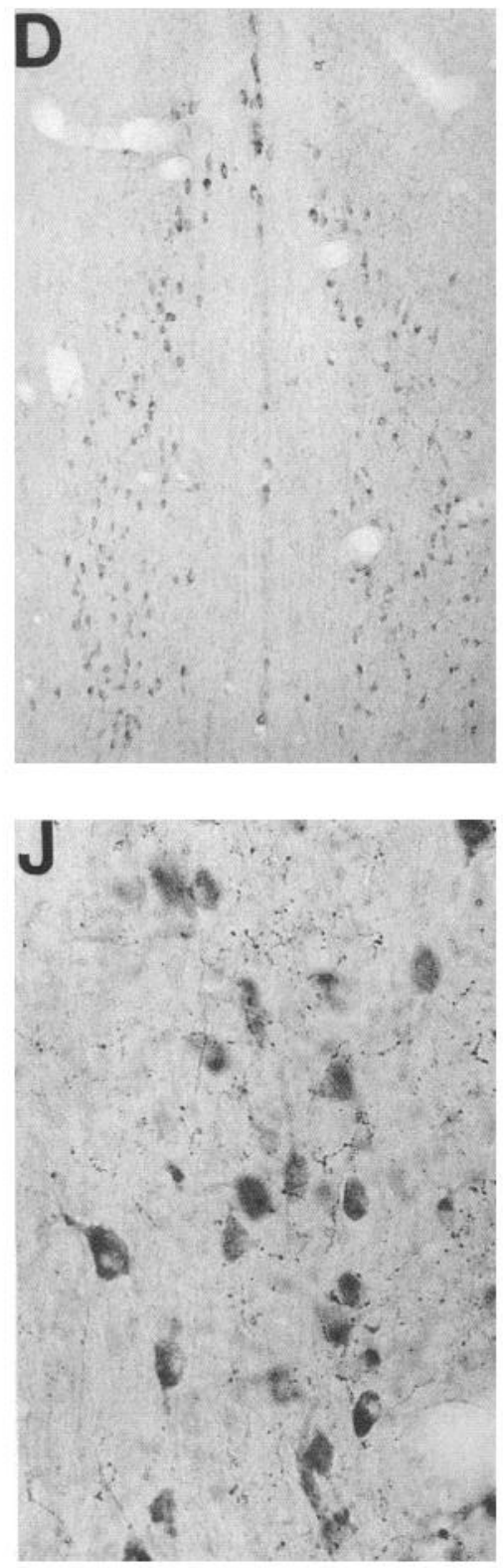

Adult
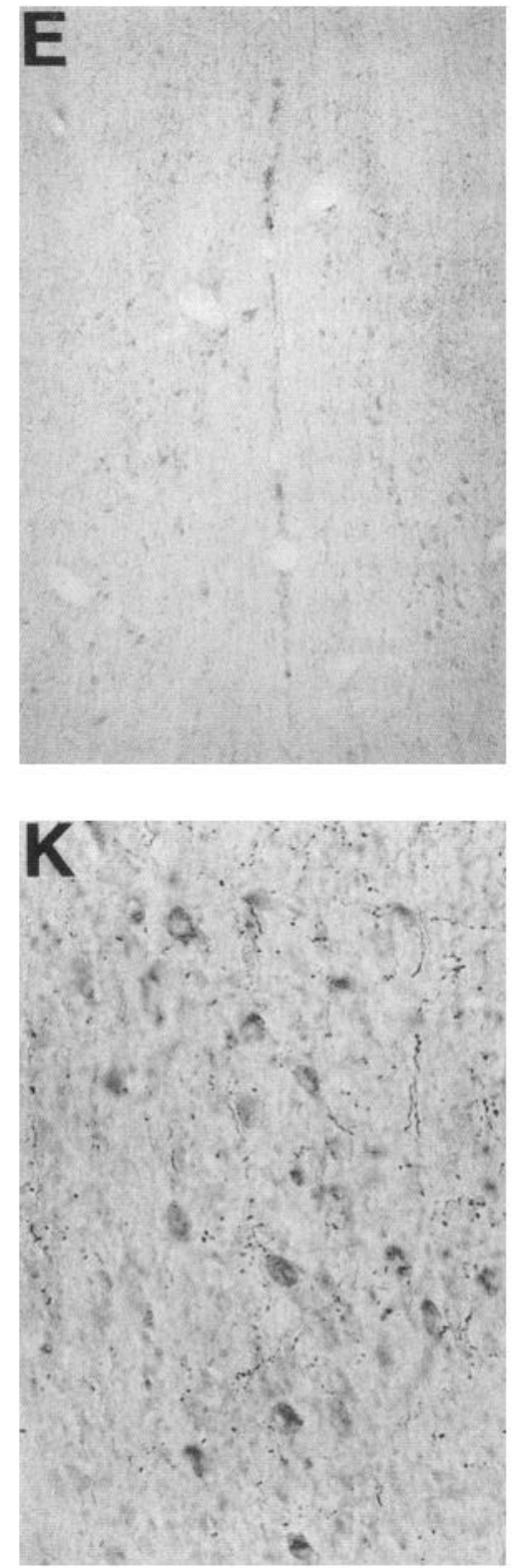

\section{Hippocampus}
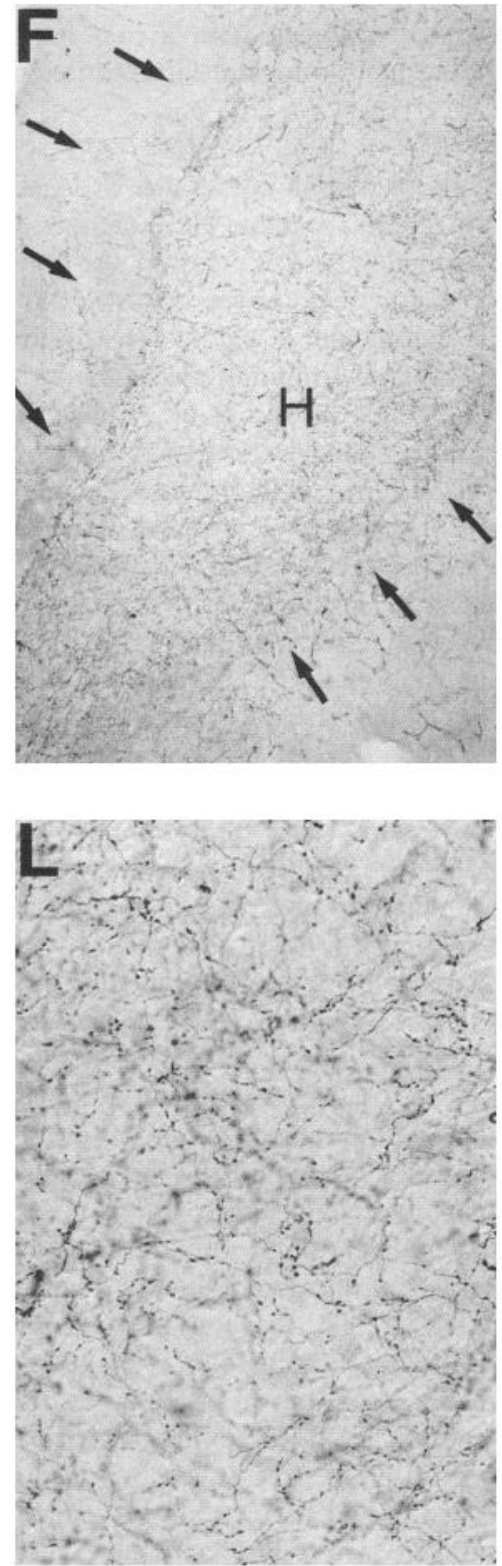

Figure 5. Continued.

iments demonstrated that in GAM-treated animals, ChAT expression was about $70 \%$ of that in NGS-treated animals $(p<$ 0.01; Fig. $11 C$ ). TrkA mRNA was also decreased. In four experiments, TrkA mRNA levels were decreased $28 \%$ by GAM $(p<0.05$; Fig. $11 B)$. These data are evidence that endogenous NGF regulates expression of ChAT and TrkA.

\section{Endogenous NGF regulated the size of basal forebrain cholinergic cell bodies}

An important manifestation of neuronal differentiation is increased cell body size. In earlier studies using immunostaining for p75NGFR, it was shown that the size of cell bodies in the nucleus basalis of Meynert markedly increased from PD0 to PD20. Thereafter, there was a decrease in size and by adulthood these neurons were $\sim 62 \%$ of their maximum (Koh and Loy, 1989). The size of TrkA immunoreactive neurons in the MSN followed a similar pattern. From PD0 to PD21 there was a $128 \%$ increase. Adult neurons were $79 \%$ of their size at PD21 (Figs. $5,12 A)$. To ask whether exogenous NGF could increase cell size, NGF (30 $\mu \mathrm{g})$ or vehicle was injected intraventricularly on PD3 and PD5 and animals were sacrificed on PD7. NGF infusion caused a significant, $26 \%$ increase in the size of TrkA-positive cell bodies (Fig. 12B). As a result of NGF treatment, PD7 neurons were equal in size to untreated cells at PD11.

To ask whether endogenous NGF regulated the size of developing cholinergic neurons, we infused GAM, or NGS as control, using the protocol given above. Following GAM treatment, the size of TrkA-positive neurons was decreased by $18 \%$, a result 
that was significant (Fig. 12C). Thus, NGF antibody infusion suppressed the normal developmental increase in cell size. The data for the effects of NGF and NGF antibody infusions on cell body size are consistent with a role for endogenous NGF in regulating the morphological differentiation of $\mathrm{BFCNs}$.

\section{Discussion}

A large body of data indicates that TrkA is a signal transducing receptor for NGF. To define NGF actions, it is essential to document both the locus of expression and regulation of TrkA. TrkA expression is restricted in the mature CNS to eight populations of neurons (Holtzman et al., 1994). Cholinergic neurons in the striatum and basal forebrain also contain TrkA mRNA (Holtzman et al., 1992a; Merlio et al., 1992). TrkA and ChAT have also been colocalized by immunostaining to these cells (Steininger et al., 1993). NGF infusion in adult subjects has been shown to enhance gene expression in these cells (Higgins et al., 1989; Holtzman et al., 1992a), increase cholinergic neurochemical parameters (Hefti et al., 1989) and increase the size of cholinergic neurons (Holtzman et al., 1993, 1994). TrkA thus marks NGF responsive mature CNS neurons. NGF also has robust effects on developing BFCNs (Gnahn et al., 1983; Mobley et al., 1986; Johnston et al., 1987). For example, a single NGF injection at PD2 produced significant increases in ChAT activity in both basal forebrain and hippocampus (Johnston et al., 1987). In the studies recorded here, we asked whether TrkA was present to mediate the NGF response in the early postnatal period. In doing so we made a note of a recent investigation using ISHH that demonstrated TrkA mRNA in the basal forebrain of developing rats (Ringstedt et al., 1993). However, in those studies the cells containing TrkA mRNA were not well defined, nor was there evidence for $\operatorname{TrkA}$ expression in the early postnatal period. Our studies for the localization of TrkA mRNA and ChAT mRNA showed that both mRNAs were present in basal forebrain neurons and gave evidence for their codistribution. Using immunocytochemistry, TrkA protein was also present; again, TrkA-positive cells corresponded in distribution to that for ChAT mRNA-positive cells. Our current data and those from earlier studies (Holtzman et al., 1992, 1994) suggest that gene expression for TrkA is present in cholinergic neurons throughout the postnatal period and into adulthood. NGF infusion in neonates was shown to induce TrkA tyrosine phosphorylation, evidence that NGF could bind to TrkA to activate signaling in these neurons. Therefore, it appears that TrkA is present to mediate NGF actions in developing basal forebrain neurons.

We found that expression of $\operatorname{TrkA}$ was highly regulated during development. Low levels of mRNA were present in the first postnatal days; marked increases were noted thereafter. The intensity of immunostaining for TrkA was increased during this same period and, by Western blot, TrkA protein levels followed a pattern similar to that for the mRNA by Northern blot. These findings suggest that gene expression for TrkA is regulated through controls on the amount of mRNA. The distribution of TrkA protein within neurons also appeared to be regulated during development. There was an increase in immunostaining in fibers in the basal forebrain at PD21 and in the adult. There was a corresponding increase in hippocampal fiber staining at these ages. Increased fiber staining from PD21 to the adult occurred at the same time that TrkA immunostaining in cell bodies was decreasing. By Western blot, the TrkA protein level in the septum at PD21 was approximately equal to that in the adult and the level in hippocampus increased during this interval. The data
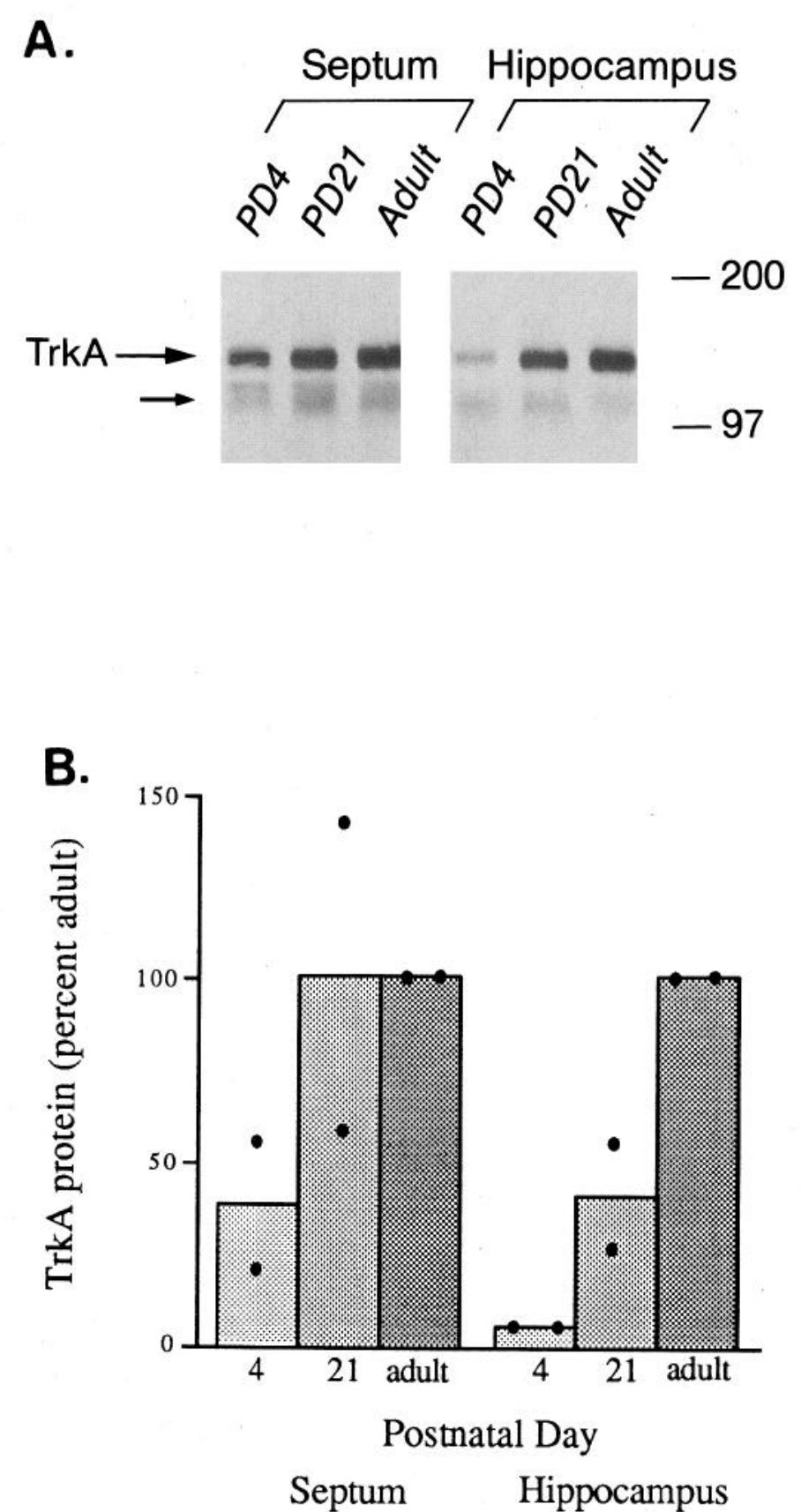

Figure 6. TrkA protein in the developing septum and hippocampus. $A$, Western blot analysis of TrkA from the septum (lanes $1-3$ ) and hippocampus (lanes 4-6) from PD4, PD21, and adult rats. Equal amounts of protein from lysates of the pooled septums from 6-10 animals or the pooled hippocampus of 6-10 animals were immunoprecipitated with 1088, blotted and probed with RTA. The bands below TrkA (small arrow) are possibly underglycosylated forms. B, Quantitation of TrkA protein. Data from two experiments are presented. Septum: PD4 $=37 \% ;$ PD21 $=99.9 \%$; adult $=100 \%$. Hippocampus: PD4 $=4.8 \%$; PD21 $=40.2 \%$; adult $=100 \%$.

suggest that increasing maturation of BFCNs was associated with increased movement of TrkA from cell bodies to processes. As a result of this redistribution, a larger fraction of NGF receptors would be present in the hippocampus, the source of NGF (Large et al., 1986; Auburger et al., 1987).

Very similar patterns for developmental regulation of TrkA and ChAT suggested that they may be regulated similarly. Due, 
A.

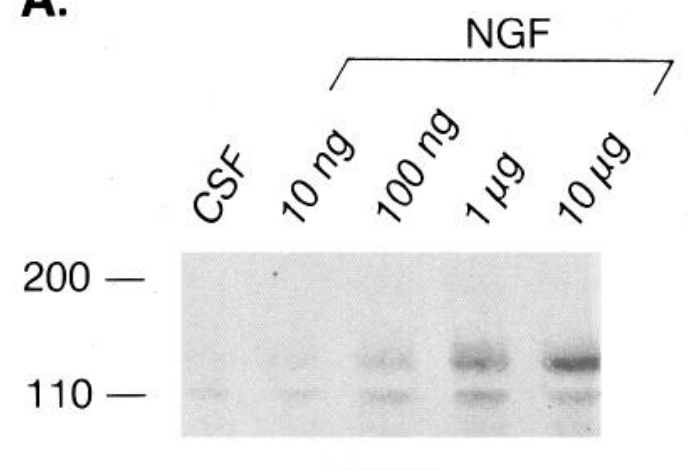

PD7
B.

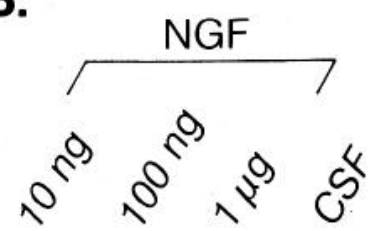

\section{ptyr \\ Septum}

C.
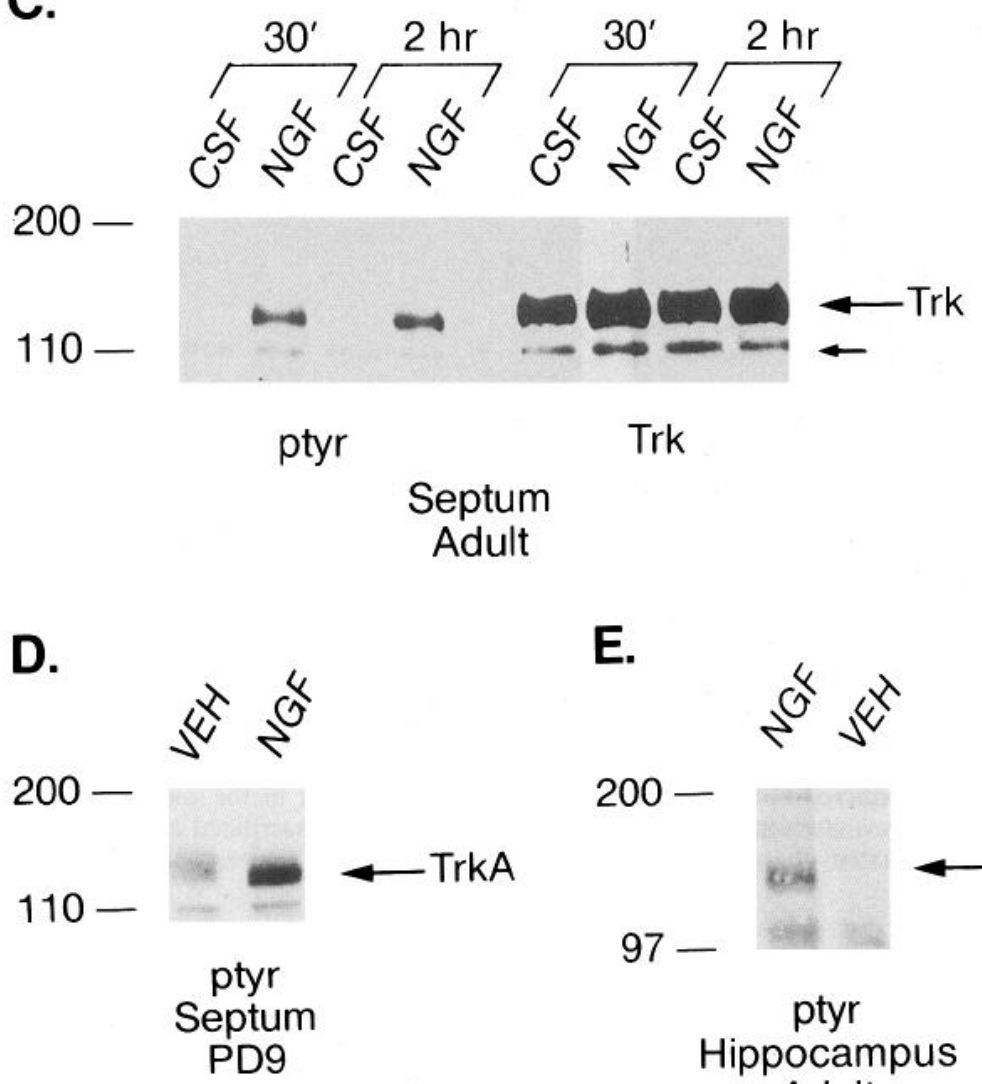

E.

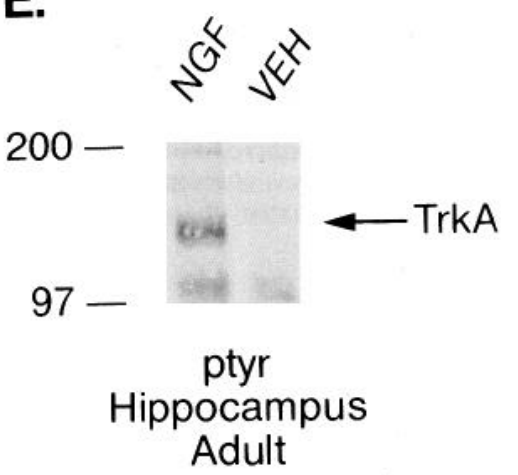

Figure 7. NGF induced TrkA tyrosine phosphorylation in vivo and in vitro. $A$ and $B$, In dose-response experiments, NGF $(10 \mathrm{ng}, 100 \mathrm{ng}, 1 \mu \mathrm{g}$, or $10 \mu \mathrm{g}$ ), or artificial CSF as the vehicle control, was injected into the right lateral ventricle. Septal tissues of PD7 and adult rats were dissected $30 \mathrm{~min}$ postinjection. The tissue lysates were immunoprecipitated with pan-trk antiserum, and Western blots of Trk proteins were probed with an anti-phosphotyrosine antibody. Reprobing the blot with a TrkA specific antibody showed that comparable amounts of TrkA protein were loaded. $C$, NGF (1 $\mu \mathrm{g}$ ) was injected into the right lateral ventricle of adult rats. Septal tissues were dissected either $30 \mathrm{~min}$ or $2 \mathrm{hr}$ postinjection. The lysate was immunoprecipitated and evaluated as above; blots were then stripped and reprobed with pan-trk antiserum (203). The band below Trk (small arrow) is possibly an underglycosylated form. $D$, Tyrosine phosphorylation of TrkA in rat septum at PD9. Animals received intraventricular injections of NGF $(30 \mu \mathrm{g})$ at PD5 and -7 and were sacrificed at PD9. E, TrkA tyrosine phosphorylation in adult hippocampus following NGF treatment in vitro. Correcting for the amount of TrkA loaded, the increase in TrkA phosphorylation with NGF was approximately fourfold. This experiment was done twice with similar results. at least in part, to increased levels of ChAT mRNA (Cavichioli et al., 1991), ChAT activity is induced by NGF injection in developing basal forebrain (Gnahn et al., 1983; Mobley et al., 1986; Johnston et al., 1987). To pursue the possibility that NGF regulated both ChAT and TrkA, we carried out two series of experiments. In the first, exogenous NGF was infused during the first postnatal week. NGF administration produced a dramatic and long-lasting increase in TrkA activation. Following this there was an increase in mRNA levels for both ChAT and TrkA. The increase in ChAT expression was greater than that for TrkA. It is possible that a different injection schedule would have produced a more dramatic increase in TrkA expression. In PC12 cells, prolonged exposure to NGF is required to demonstrate a response and TrkA mRNA levels increase over several days (Zhou, Grimes, Valletta, and Mobley, unpublished observations). Nevertheless, the current data does suggest differences in the mechanism of induction of these genes by exogenous NGF. Our findings for TrkA complement in vivo studies on mature BFCNs (Holtzman et al., 1992a) as well as in vitro studies on PC12 cells (Holtzman et al., 1992a; Meakin et al., 1992). In a second set of experiments, NGF antibodies were infused from PD3 through 10. NGF antibodies suppressed the normal developmental increases for both ChAT and Trk mRNA. A role for endogenous NGF in the differentiation of BFCNs was also sug- 

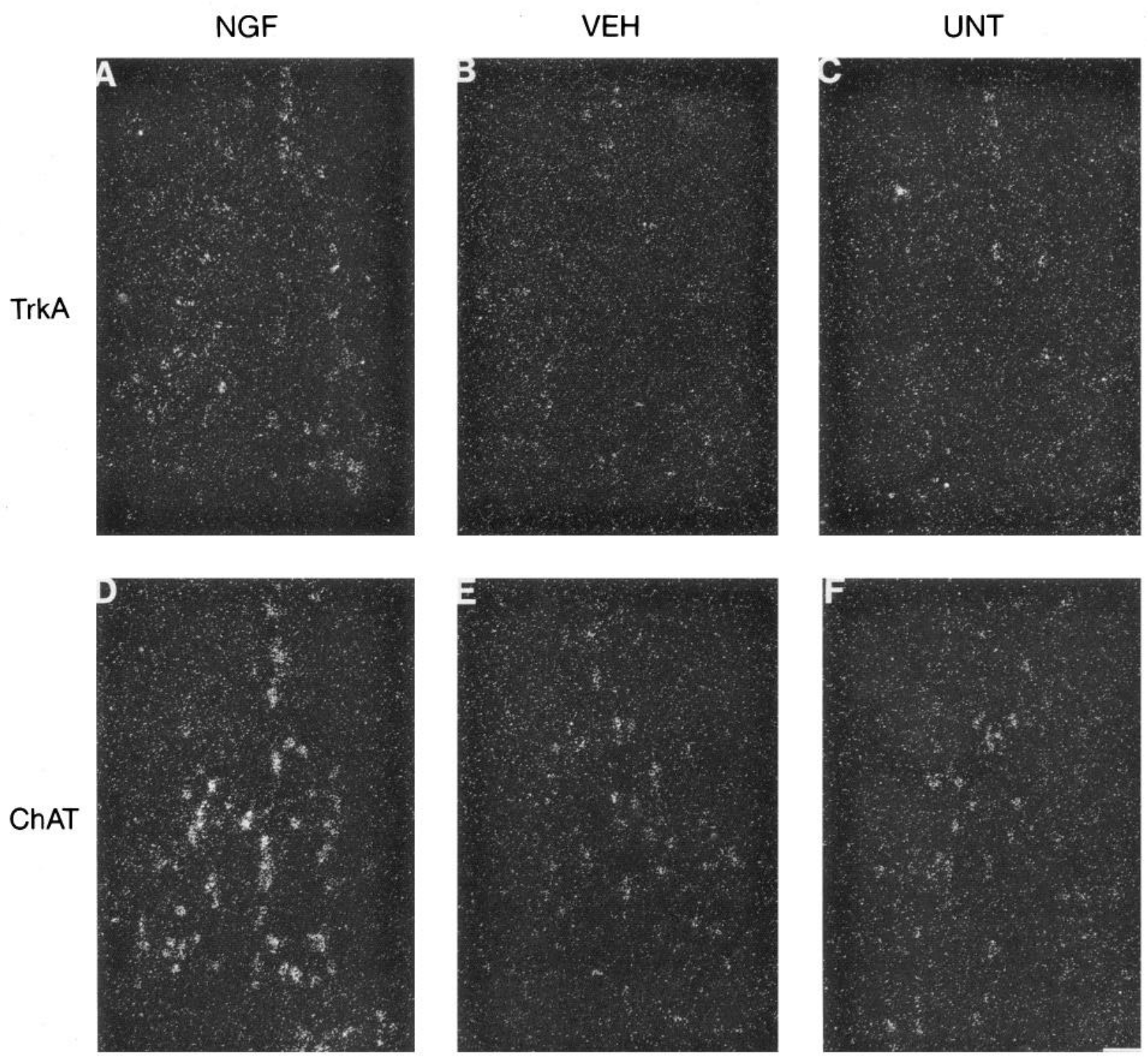

Figure 8. NGF induces expression of TrkA and ChAT. Dark-field photomicrographs showing TrkA and ChAT mRNA in the medial septum following administration of NGF or vehicle. NGF $(30 \mu \mathrm{g})$ was injected intraventricularly at PD3 and PD5. Animals were sacrificed at PD7. TrkA $(A-C)$ and ChAT $(D-F)$ mRNA were examined by ISHH. $A$ and $D$, NGF-treated; $B$ and $E$, vehicle-treated control; $C$ and $F$, untreated. White scale bar, $100 \mu \mathrm{m}$.

gested by the data for cell body size. While exogenous NGF induced an increase, NGF antibodies suppressed the normal increase. Interestingly, the extent of the latter was similar for ChAT and $\operatorname{Trk} A$. These data argue strongly that endogenous NGF regulates the morphological and biochemical differentiation of BFCNs. Given the data for the distribution and activation of TrkA, this receptor may mediate these effects. However, the data reported herein do not exclude a role for p75NGFR in this process. Indeed, we have found that the development regulation of this receptor is similar to that for TrkA (Springer, Li, Holtzman, and Mobley, unpublished observations).

Several lines of evidence have suggested that NGF is a targetderived neurotrophic factor for developing BFCNs. First, NGF is produced in the hippocampus and neocortex, the target zone of BFCNs (Korsching et al., 1985; Shelton and Reichardt, 1986; Whittemore et al., 1986; Ayer-LeLievre et al., 1988; Ernfors et al., 1990; Phillips et al., 1990; Gall et al., 1991). Second, as demonstrated here, there is evidence to indicate that developing
BFCNs express TrkA. Third, exogenous NGF enhances the neurochemical differentiation of BFCNs, inducing expression of a number of developmentally regulated genes (Gnahn et al., 1983; Mobley et al., 1986, 1988). Fourth, there is a close temporal correspondence during development between endogenous NGF levels in the hippocampus and neocortex and the activity in the basal forebrain of ChAT (Large et al., 1986; Auburger et al., 1987). The most convincing earlier evidence for a role of endogenous NGF in the PNS came from studies in which NGF antibodies were used to block the actions of NGF. Death of sympathetic and DRG sensory ganglion neurons resulted from the presence of NGF antibodies at the proper developmental stage (Levi-Montalcini and Booker, 1960; Johnson et al., 1980; Longo et al., 1993). There are relatively few data for use of NGF antibodies in the CNS. Nevertheless, intraventricular administration of NGF antibodies to neonatal rats appeared to modestly reduce ChAT activity in basal forebrain and its projections (Vantini et al., 1989). This finding pointed to endoge- 

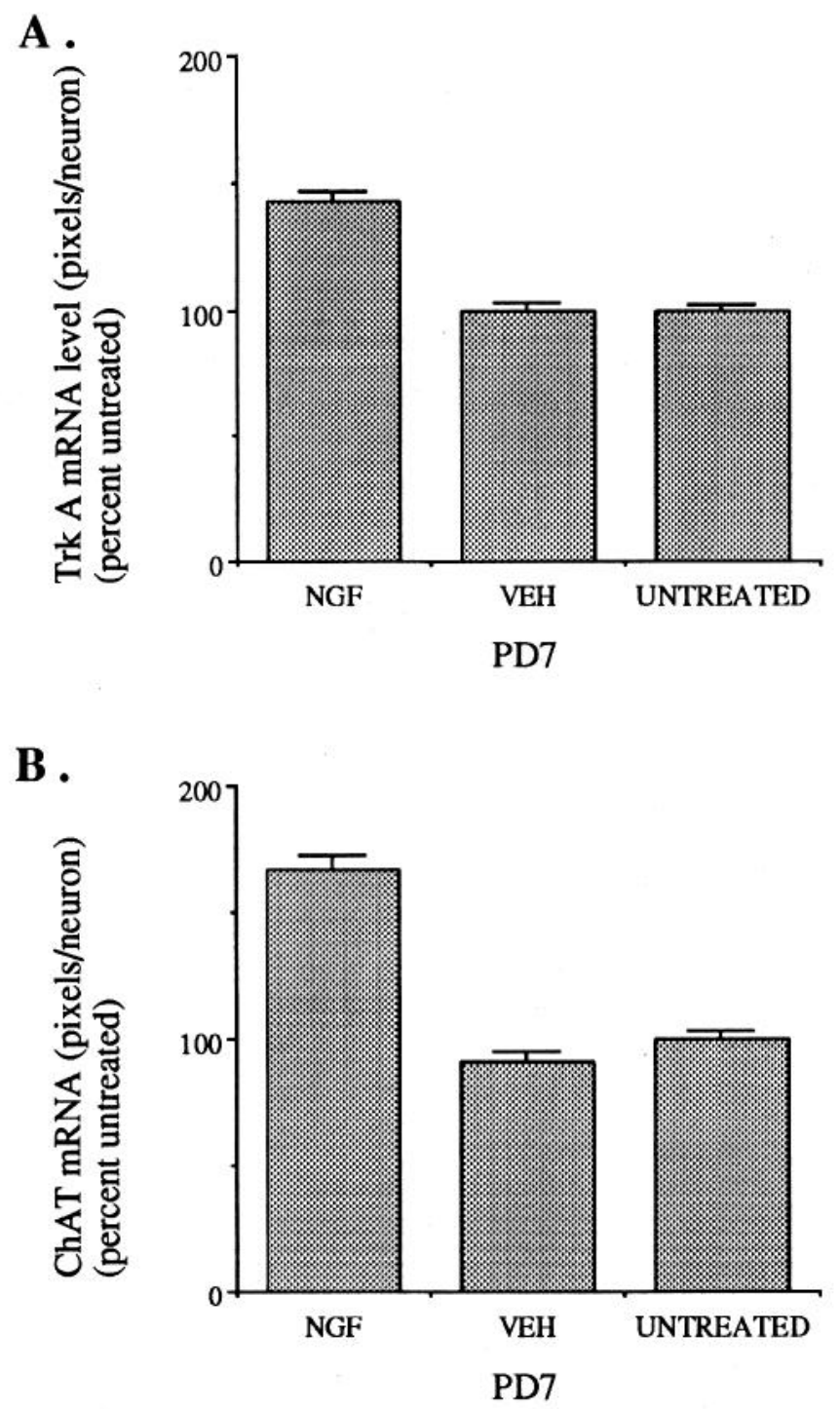

Figure 9. Quantitation of NGF-induced expression of TrkA and ChAT. Sections from NGF-treated $(n=3)$, vehicle-treated $(n=3)$, and untreated $(n=3)$ animals were hybridized with TrkA or ChAT antisense riboprobes, and the number of grains (pixels) over MSN was counted. Values are mean \pm SEM as percentage of untreated animals. (TrkA: $\mathrm{NGF}=140 \% \pm 4 \%, n=240$; vehicle $=100 \% \pm 3 \%, n=194$; untreated $=100 \% \pm 2 \%, n=238$; NGF vs vehicle or untreated, $p<$ 0.001. ChAT: NGF $=167 \% \pm 6 \%, n=150$; vehicle $=91 \% \pm 4 \%$, $n=150$; untreated $=100 \% \pm 3 \%, n=150$; NGF versus vehicle or untreated, $p<0.001$ ).

nous NGF as important for BFCN development. However, these studies were carried out before it was known that other neurotrophins existed that could act on BFCNs. Therefore, the possibility that NGF antibodies acted by blocking the actions of other neurotrophins was addressed in the current study. BDNF, NT- 3 and NT-4/5 are the other known members of the neurotrophin family (Persson, 1993). While BDNF and NT-3 are expressed in hippocampus (Ernfors et al., 1990; Maisonpierre et al., 1990; Phillips et al., 1990), there is little NT-4 expression in brain (Ip et al., 1992). The receptor for BDNF is TrkB; BFCNs contain TrkB mRNA (Merlio et al., 1992) and as shown herein and elsewhere, respond to BDNF in vitro (Alderson et al., 1990; Knüsel and Hefti, 1993) and in vivo (Knüsel et al., 1992; Koliatsos et al., 1994). Expression of TrkC, the gene en-
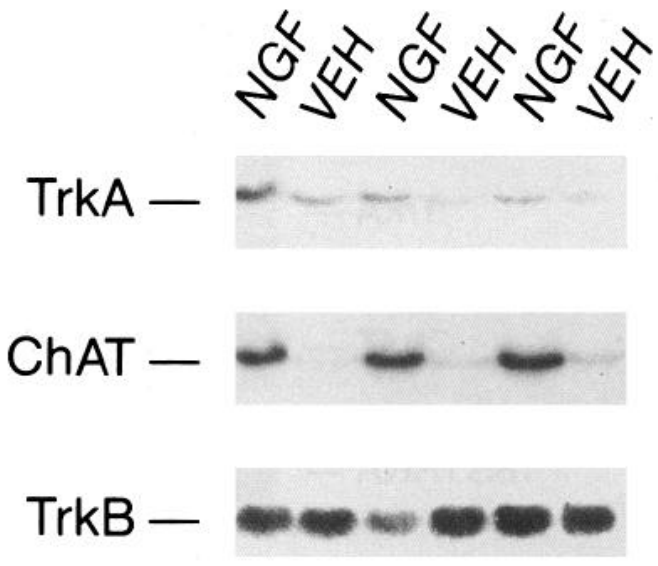

18S rRNA -

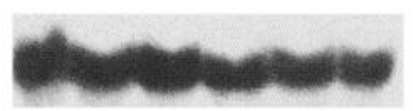

Figure 10. Northern blot analysis for NGF treatment effects on TrkA, ChAT, and TrkB. Total RNA was prepared from the septums of animals treated with NGF or vehicle on PD1, -3 , and -5 and then sacrificed on PD7. Each tissue pool contained five or six septums. Forty micrograms of RNA was loaded in each lane. Blots were hybridized with ${ }^{32} \mathrm{P}$ labeled TrkA cDNA probe, and then reprobed with the ChAT or TrkB probe. Blots were finally reprobed with $18 \mathrm{~S}$ rRNA probe to control for RNA loading. The results were examined by PhosphorImager and NGF-treated values were expressed as percent of vehicle-treated values. TrkA = $114 \pm 4 \%$ [a total of 10 determinations $(n)$ on three separate samples $(N)], p<0.05 ;$ ChAT $=217 \pm 7 \%(n=8, N=3), p<0.001$; TrkB $=100 \pm 6 \%(n=5, N=3), p>0.05$.

coding the receptor for NT-3, also appears to be expressed in BFCNs (Merlio et al., 1992) and these neurons respond to NT-3 in vitro, as shown elsewhere (Knusel and Hefti, 1993) and here. Thus, it is possible that the actions of endogenous BDNF and NT-3 could mimic those of NGF. We asked whether NGF antibodies influenced the activity of BDNF and NT-3 in vitro. At the GAM concentration achieved in brain tissue at PD8, there was complete inhibition of NGF actions on both DRG neurons and BFCNs. However, there was limited cross-reactivity of GAM with BDNF and NT-3 (0.5\%), and we detected no inhibition of BDNF or NT-3 actions on either DRG neurons or BFCNs at the concentration of GAM present in brain. Indeed, even at a concentration higher than those measured at PD8, GAM failed to inhibit BDNF or NT-3 (data not shown). The level of GAM present in brain together with the very limited cross-reactivity of GAM with BDNF and NT-3 makes it unlikely that a concentration sufficient to neutralize these neurotrophins was achieved in vivo. We cannot dismiss the possibility that an as yet undiscovered neurotrophin was inhibited by GAM, but these findings provide strong support for the view that endogenous NGF acts as a neurotrophic factor for BFCNs.

NGF antibody injections did not result in complete suppression of developmental increases in gene expression and cell body size. If endogenous NGF was solely responsible for regulating these measures, we might have expected NGF antibodies to completely inhibit the increases. That this was not the case suggests at least two possibilities. The first is that the antibodies were only partially effective in sequestering NGF. A second possibility is that a factor other than NGF was responsible, at least in part, for the development of BFCNs. The involvement of an additional factor(s) in BFCN development is supported by recent 
A.

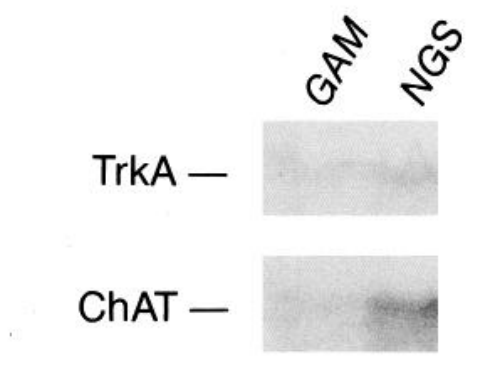

$18 \mathrm{~S}$ rRNA -

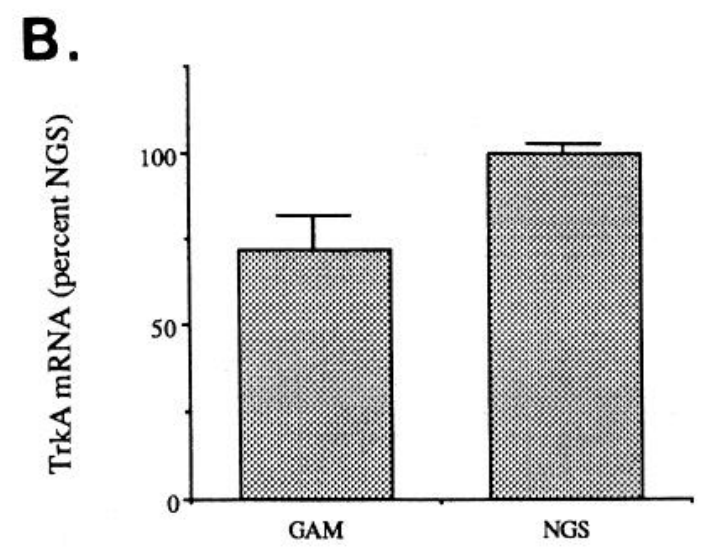

C.

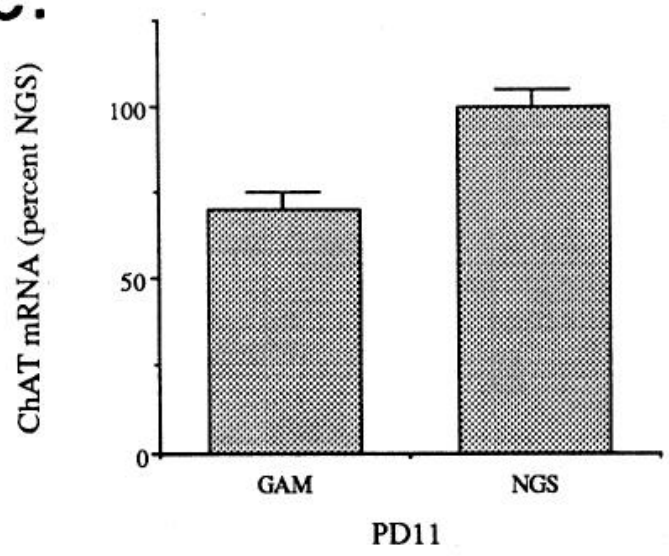

Figure 11. Effect of NGF antiserum (GAM) infusion on gene expression for TrkA and ChAT. A, Northern blots analysis of $20 \mu \mathrm{g}$ samples of total RNA from pooled septums of 10-12 animals at PD11. Blots were hybridized with ${ }^{32} \mathrm{P}$ labeled TrkA or ChAT cDNA probes. Blots were reprobed with an $18 \mathrm{~S}$ rRNA probe to control for RNA loading. GAM, Anti-NGF antiserum; NGS, nonimmune goat serum. Bar graphs show quantitative data for TrkA $(B)$ and ChAT $(C)$. Data were normalized to those for untreated subjects. GAM values are given as the percentage of the value in NGS-treated (control) animals (mean \pm SEM, $n=4)$. (TrkA: GAM $=72 \% \pm 10 \%$; NGS $=100 \%$ $\pm 2.9 \%$; GAM vs NGS, $p<0.05$. ChAT: GAM $=70 \% \pm 5 \%$; NGS $=100 \% \pm 5 \%$; GAM vs NGS, $p<0.01$, Student's $t$ test). The NGS value was $68 \%$ of that in untreated subjects for TrkA mRNA and $82 \%$ for ChAT mRNA. data from studies of mice in which the genes for NGF and TrkA have been disrupted. In the case of the former, BFCNs were present but were smaller and more lightly immunostained for ChAT and TrkA (Crowley et al., 1994). BFCNs were also present following TrkA gene disruption, but there was decreased staining for $\mathrm{AChE}$ in the hippocampus and cortex (Smeyne et al., 1994; also see Snider, 1994). As indicated earlier, BDNF and NT-3 are logical candidates to act on BFCNs. BDNF is especially attractive in that the developmental pattern of gene expression in hippocampus resembles that for NGF (Maisonpierre et al., 1990). Nevertheless, there was no evidence for a change in BFCNs in mice in which the BDNF gene was disrupted (Jones et al., 1994).

We discovered an interesting discrepancy between the data from ISHH and Northern analysis. While both methods documented marked increases in expression in the early postnatal period, by ISHH mRNA levels plateaued between PD11 and PD21 before falling in the adult. Northern blots, on the other hand, showed increases between PD11 and PD21 with maintenance of relatively high levels in the adult. The source of the discrepancy is uncertain. However, the correspondence between Northern blots, which quantitatively measure tissue mRNA, and the data for TrkA protein by Western blot and ChAT activity by enzyme assay (Large et al., 1986) argues that the discrepancy arises from inability of ISHH to detect increased mRNA at later developmental stages. A difference due to methodological issues is also suggested by the fact that TrkA and ChAT mRNA levels were affected similarly. One possibility is that mRNA species are more widely distributed within mature neurons and are thus more difficult to detect by ISHH. However, cell body size alone would not explain the difference. PD11 neurons were larger on average than those in the adult. Thus, a different distribution of mRNA could not be due to simple dispersion of RNA within a larger perikaryon. Another possibility is that relative access of radiolabeled probes was greater in younger neurons. Of note, Ringstedt et al. (1993) using ISHH showed an increase in TrkA mRNA between PD14 and PD28 in the rat basal forebrain. Our methods differed in two ways from theirs. They used a 48-mer oligonucleotide, a shorter probe than ours. Second, we briefly fixed tissue sections in 3\% paraformaldehyde. Each of these differences could hamper probe entry in more mature neurons and thereby have accounted for our findings. The discrepancy between ISHH and Northern data encourages the use of Northern analysis or other RNA quantitative methods in addition to ISHH in studies of the developing CNS.

NGF appears to regulate TrkA and its signaling on at least three levels. The first is the increase in TrkA phosphorylation that accompanies NGF treatment. This event is essential to NGF signalling and in our experiments was remarkably persistent in comparison to its effects on PC12 cells in vitro (Hempstead et al., 1992). Downregulation of TrkA receptors is a second level for regulation. NGF binding has been shown within minutes to dramatically decrease TrkA at the cell surface (Hosang and Shooter, 1987). Indeed, in recent studies NGF treatment for one hour produced a decrease not only in surface TrkA but also in the level of total cellular mature TrkA to approximately $30 \%$ of that present initially (Zhou, Grimes, Valletta, and Mobley, unpublished observations). Whether downregulation of activated TrkA occurs at the surface of NGF-stimulated BFCNs is uncertain. If it does occur, increased TrkA expression could be a compensatory response, that is, a third level for regulation. We failed to see a change in TrkA protein in our studies. However, the 
A.

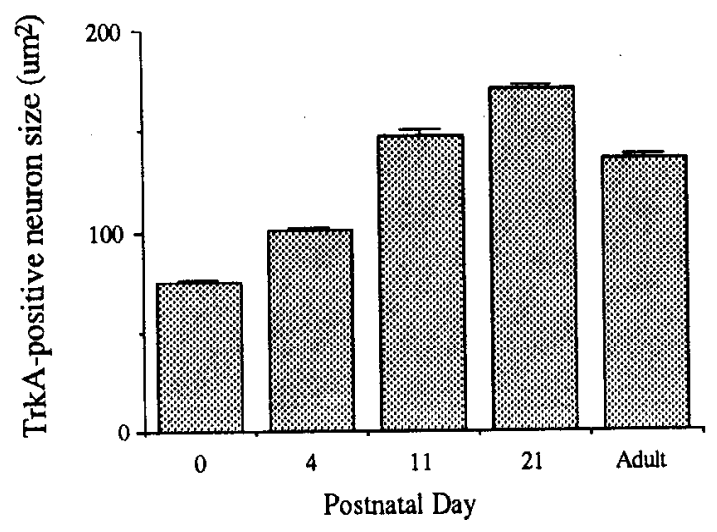

B.

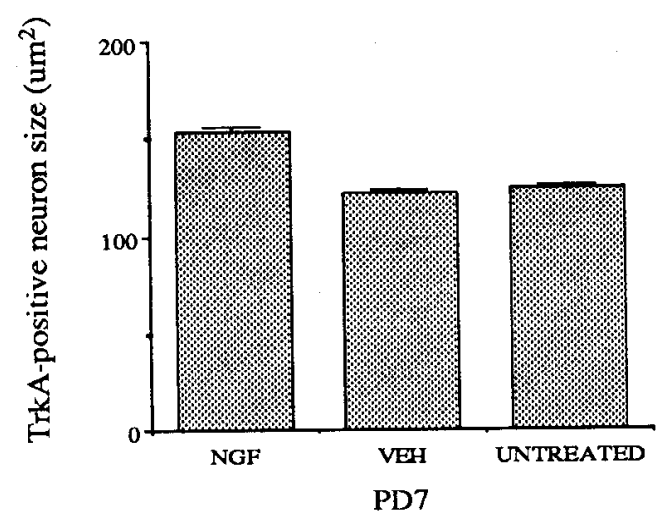

C.

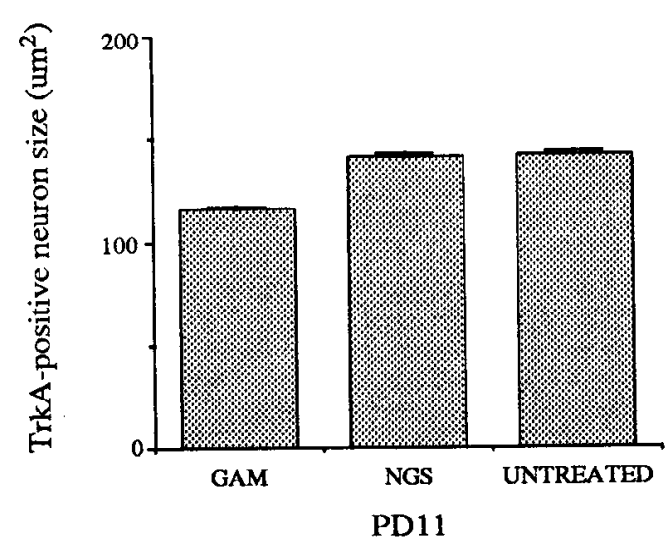

Figure 12. Effect of exogenous and endogenous NGF on TrkA immunoreactive cell size in the septum. A, TrkA-positive cell size in the normal developing septum. Two animals were examined at each age All data are mean $\pm \operatorname{SEM}\left(\mu \mathrm{m}^{2}\right)$. PD0 $=74.2 \pm 0.97, n=168$ neurons; PD4 $=100 \pm 1.46, n=167$; PD11 $=147.4 \pm 2.68, n=$ $181 ; \mathrm{PD} 21=169.4 \pm 2.8, n=195 ;$ adult $=135.5 \pm 1.95, n=175$. $B$, Effect of exogenous NGF on TrkA-positive cell size. Three animals were examined in each group. NGF-treated $=153.4 \pm 2.4, n=297$; vehicle $=122.1 \pm 1.6, n=310$; untreated $=124.6 \pm 1.8, n=314$; NGF versus vehicle or untreated, $p<0.001$. $C$, Effect of NGF antiserum (GAM) on TrkA-positive cell size. Each group had four animals. GAM-treated $=116.3 \pm 1.2, n=410 ;$ NGS $=141.3 \pm 1.5, n=432$; untreated $=142.1 \pm 1.6, n=435$; GAM-treated versus NGS or untreated, $p<0.001$. increase in mRNA levels due to exogenous NGF was small. Other treatment schedules may result in larger increases in gene expression. Positive regulation of TrkA expression by NGF would provide the neuron with a means for replacing TrkA at the cell surface to allow for continued signaling. This mechanism might be especially useful in devcloping BFCNs, allowing them to adjust to NGF levels present in the expanding early postnatal target. Interestingly, upregulation of TrkA expression may produce an increase in receptor numbers and signaling. Studies in PC12 cells show that increased expression, whether due to NGF treatment or to transfection with a TrkA cDNA, produced such changes (Bernd and Greene, 1984; Hempstead et al., 1992; Zhou, Grimes, Vallella, and Mobley, unpublished observations). Thus, neurons sensitized or "primed" by prior exposure to NGF may be more responsive to it. The apparent enhanced dose-response of adult BFCNs to NGF reported here suggests that this could occur in vivo. Through regulation of the activity and expression of $\operatorname{TrkA}$, neurons may be provided with the means for maintaining or even potentiating their responses to NGF.

\section{References}

Alderson RF, Alterman AL, Barde YA, Lindsay RM (1990) Brainderived neurotrophic factor increases survival and differentiated functions of rat septal cholinergic neurons in culture. Neuron 5:297-306.

Altar CA, Burton LE, Bennett GL, Dugich-Djordjevic M (1991) Recombinant human nerve growth factor is biologically active and labels novel high-affinity binding sites in rat brain. Proc Natl Acad Sci USA 88:281-285.

Auburger G, Heumann R, Hellweg R, Korsching S, Thoenen H (1987) Developmental changes of nerve growth factor and its $\mathrm{mRNA}$ in the rat hippocampus: comparison with choline acetyltransferase. Dev Biol 120:322-328.

Ayer-LeLievre C, Olson L, Ebendal T, Seiger A, Persson H (1988) Expression of the $\beta$-nerve growth factor gene in hippocampal neurons. Science 240:1339-1341.

Bernd P, Greene LA (1984) Association of ${ }^{125}$ I-nerve growth factor with PC12 pheochromocytoma cells. J Biol Chem 259:15509-15516.

Bothwell M (1991) Keeping track of neurotrophin reccptors. Cell 65: 915-918.

Bowman L, Rabin B, Schlessinger D (1981) Multiple ribosomal RNA cleavage pathways in mammalian cells. Nucleic Acids Res 9:49514966.

Carter AN, Downes CP (1992) Phosphatidylinositol 3-kinase is activated by nerve growth factor and epidermal growth factor in PC12 cells. J Biol Chem 267:14563-14567.

Cavicchioli L, Flanigan TP. Dickson JG, Vantini G, Dal Toso R, Fusco M, Walsh FS, Leon A (1991) Choline acetyltransferase messenger RNA expression in developing and adult rat brain: regulation by nerve growth factor. Mol Brain Res 9:319-325.

Chao MV (1992) Neurotrophin receptors: a window into neuronal differentiation. Neuron 9:583-593.

Chirgwin JM, Przybyla AE, MacDonald RJ, Rutter WJ (1979) Isolation of biologically active ribonucleic acid from sources enriched in ribonuclease. Biochemistry 18:5294-5299.

Clary DO, Weskamp G, Austin LR, Reichardt LF (1994) TrkA crosslinking mimics neuronal responses to growth factor. Mol Biol Cell 5:549-563.

Crowley C, Spencer SD, Nishimura MC, Chen KS, Pitts-Meek S, Armanini MP, Ling LH, McMahon SB, Shelton DL, Levinson AD, Phillips HS (1994) Mice lacking nerve growth factor display perinatal loss of sensory and sympathetic neurons yet develop basal forebrain cholinergic neurons. Cell 76:1001-1011.

Crutcher KA, Scott SA, Liang S, Everson WV, Weingartner J (1993) Detection of NGF-like activity in human brain tissue: increased levels in Alzheimer's disease. J Neurosci 13:2540-2550.

Ernfors P, Wetmorc C, Olson L, Persson H (1990) Idèntification of cells in rat brain and peripheral tissues expressing mRNA for members of the nerve growth factor family. Neuron 5:511-526.

Fantl WJ, Johnson DE, Williams LT (1993) Signalling by receptor tyrosine kinases. Annu Rev Biochem 62:453-481. 
Fonnum $F$ (1975) A rapid radiochemical method for the determination of choline acetyltransferase. J Neurochem 24:407-409.

Gall C, Murray K, Isackson PJ (1991) Kainic acid-induced seizures stimulate increased expression of nerve growth factor mRNA in rat hippocampus. Mol Brain Res 9:113-123.

Gnahn H, Hefti F, Heumann R, Schwab ME, Thoenen H (1983) NGF mediated increase of choline acetyltransferase (ChAT) in the neonatal rat forebrain: evidence for a physiological role of NGF in the brain? Dev Brain Res 9:45-52.

Goedert M, Otten U, Hunt SP, Bond A, Chapman D, Schlumpf M (1984) Biochemical and anatomical effects of antibodies against nerve growth factor on developing rat sensory ganglia. Proc Natl Acad Sci USA 81:1580-1584.

Green SH, Greene LA (1986) A single $\mathrm{M}_{r}=103,000{ }^{125} \mathrm{I}-\beta$-nerve growth factor-affinity-labeled species represents both the low and high affinity forms of the nerve growth factor receptor. J Biol Chem $261: 15316-15326$.

Grimes M, Zhou J, Li Y, Holtzman DH, Mobley WC (1993) Neurotrophin signalling in the nervous system. Semin Neurosci 5:239-247.

Hefti F, Hartikka J, Knusel B (1989) Function of neurotrophic factors in the adult and aging brain and their possible use in the treatment of neurodegenerative diseases. Neurobiol Aging 10:515-533.

Hempstead BL, Martin-Zanca D, Kaplan DR, Parada LF, Chao MV (1991) High-affinity NGF binding requires coexpression of the trk proto-oncogene and the low-affinity NGF receptor. Nature 350:678683.

Hempstead BL, Rabin SJ, Kaplan L, Reid S, Parada LF, Kaplan DR (1992) Overexpression of the trk tyrosine kinase rapidly accelerates nerve growth factor-induced differentiation. Neuron 9:883-896.

Higgins GA, Koh S, Chen KS, Gage FH (1989) NGF induction of NGF receptor gene expression and cholinergic neuronal hypertrophy within the basal forebrain of the adult rat. Neuron 3:247-256.

Holtzman DM, Li. Y, Parada LF, Kinsman S, Chen CK, Valletta JS, Zhou J, Long JB, Mobley WC (1992a) pl40trk mRNA marks NGFresponsive forebrain neurons: evidence that trk gene expression is induced by NGF. Neuron 9:465-478.

Holtzman DM, Bayney RM, Li Y, Khosrovi H, Berger CN, Epstein CJ, Mobley WC (1992b) Dysregulation of gene expression in mouse trisomy 16, an animal model of Down syndrome. EMBO J 11:619627 .

Holtzman DM, Li Y, Chen K, Gage $\mathrm{FH}$, Epstein CJ, Mobley WC (1993) Nerve growth factor reverses neuronal atrophy in a Down syndrome model of age-related neurodegeneration. Neurology 43: 2668-2673

Holtzman DM, Kilbridge J, Li Y, Cunningham ET, Lenn NJ, Clary DO, Reichardt LF, Mobley WC (1994) TrkA expression in the CNS: evidence for the existence of several novel NGF-responsive CNS neurons. $\mathbf{J}$ Neurosci, in press.

Hosang M, Shooter EM (1987) The internalization of nerve growth factor by high-affinity receptors on pheochromocytoma PC12 cells. EMBO J 6:1197-1202.

Ip NY, Ibáñez CF, Nye SH, McClain J, Jones PF, Gies DR, Belluscio L, Le Beau MM, Espinosa R III, Squinto SP, Persson H, Yancopoulos GD (1992) Mammalian neurotrophin-4: structure, chromosomal localization, tissue distribution, and receptor specificity. Proc Natl Acad Sci USA 89:3060-3064.

Ip NY, Stitt TN, Tapley P, Klein R, Glass DJ, Fandl J, Greene LA, Barbacid M, Yancopoulos GD (1993) Similarities and differences in the way neurotrophins interact with the trk receptors in neuronal and nonneuronal cells. Neuron 10:137-149.

Jing S, Tapley P, Barbacid M (1992) Nerve growth factor mediates signal transduction through trk homodimer receptors. Neuron 9:1067-1079

Johnson EM, Gorin PM, Brandeis LD, Pearson J (1980) Dorsal root ganglion neurons are destroyed by exposure in utero to maternal antibody to nerve growth factor. Science 210:916-918.

Johnston MV, Rutkowski JL, Wainer BH, Long JB, Mobley (1987) NGF effects on developing forebrain cholinergic neurons are regionally specific. Neurochem Res 12:985-997.

Jones KR, Fariñas I, Backus C, Reichardt LF (1994) Targeted disruption of the BDNF gene perturbs brain and sensory neuron development but not motor neuron development. Cell 76:989-999.

Kaplan DR, Martin-Zanca D, Parada LF (1991a) Tyrosine phosphorylation and tyrosine kinase activity of the trk proto-oncogene product induced by NGF. Nature 350:158-160.
Kaplan DR, Hempstead BL, Martin-zanca D, Chao MV, Parada LF (1991b) The trk proto-oncogene product: a signal transducing receptor for nerve growth factor. Science 252:554-558.

Kim UH, Fink DJ, Kim HS, Park DJ, Contreras ML, Guroff G, Rhee SG (1991) Nerve growth factor stimulates phosphorylation of phospholipase C-gamma in PC12 cells. J Biol Chem 266:1359-1362.

Klein R, Jing S, Nanduri V, O'Rourke E, Barbacid M (1991) The trk proto-oncogene encodes a receptor for nerve growth factor. Cell 65 : $189-197$.

Knüsel B, Hefti F (1993) Multiple and interactive responses of central neurons to neurotrophic factors. Semin Neurosci 5:259-267.

Knüsel B, Burton LE, Longo FM, Mobley WC, Koliatsos VE, Price DL, Hefti F (1990) Trophic actions of recombinant human nerve growth factor on cultured rat embryonic CNS cells. Exp Neurol 110: 274-283.

Knüsel B, Beck KD, Winslow JW, Rosenthal A, Burton LE, Widmer HR, Nikolics K, Hefti F (1992) Brain-derived neurotrophic factor administration protects basal forebrain cholinergic but not nigral dopaminergic neurons from degenerative changes after axotomy in the adult rat brain. J Neurosci 12:4391-4402.

Knüsel B, Rabin S, Hefti F, Kaplan D (1994) Regulated neurotrophin receptor responsiveness during neuronal migration and early differentiation. J Neurosci 14:1542-1554.

Koh S, Loy R (1989) Localization and development of nerve growth factor-sensitive rat basal forebrain neurons and their afferent projections to hippocampus and neocortex. J Neurosci 9:2999-3018.

Koliatsos VE, Price KL, Gouras GK, Cayouette MH, Burton LE, Winslow JW (1994) Highly selective effects of NGF, BDNF, and NT-3 on intact and injured basal forebrain magnocellular neurons. J Comp Neurol, in press.

Korsching S, Auburger G, Heumann R, Scott J, Thoenen H (1985) Levels of nerve growth factor and its mRNA in the central nervous system of the rat correlate with cholinergic innervation. EMBO J 4:1389-1393.

Large TH, Bodary SC, Clegg DO, Weskamp G, Otten U, Reichardt LF (1986) Nerve growth, factor gene expression in the developing rat brain. Science 234:352-355.

Levi-Montalcini R, Booker B (1960) destruction of the sympathetic ganglia in mammals by an antiserum to a nerve-growth protein. Proc Natl Acad Sci USA 46:384-391.

Longo FM, Vu T-KH, Mobley WC (1990) The in vitro biological effect of nerve growth factor is inhibited by synthetic peptides. Cell Regul 1:189-195.

Longo FM, Holtzman DM, Grimes ML, Mobley WC (1993) Nerve growth factor: actions in the peripheral and central nervous systems. Neurotrophic Factors 209-255.

Maisonpierre PC, Belluscio L, Friedman B, Alderson RF, Wiegand SJ, Furth ME, Lindsay RM, Yancopoulos GD (1990) NT-3, BDNF, and NGF in the developing rat nervous system: parallel as well as reciprocal patterns of expression. Neuron 5:501-509.

Meakin SO, Shooter EM (1991a) Molecular investigations on the highaffinity nerve growth factor receptor. Neuron 6:153-163.

Meakin SO, Shooter EM (1991b) Tyrosine kinase activity coupled to the high-affinity nerve growth factor-receptor complex. Proc Nat Acad Sci USA 88:5862-5866.

Meakin SO, Shooter EM (1992) The nerve growth factor family of receptors. Trends Neurosci 15:323-331.

Meakin SO, Suter U, Drinkwater CC, Welcher AA, Shooter EM (1992) The rat trk protooncogene product exhibits properties characteristic of the slow nerve growth factor receptor. Proc Natl $\Lambda$ cad Sci USA 89:2374-2378.

Merlio JP, Jaber EM, Persson H (1992) Molecular cloning of rat trk C and distribution of cells expressing messenger RNAs for members of the trk family in the rat central nervous system. Neuroscience 51: 513-532.

Mobley WC, Rutkowski JL, Tennekoon GI, Gemski J, Buchanan K, Johnston MV (1986) Nerve growth factor increases choline acetyltransferase activity in developing basal forebrain neurons. Mol Brain Res 1:53-62.

Mobley WC, Neve RL, Prusiner SB, McKinley MP (1988) Nerve growth factor increases mRNA levels for the prion protein and the $\beta$-amyloid precursor in developing hamster brain. Proc Natl Acad Sci USA 85:9811-9815.

Mobley WC, Woo JE, Edwards RII, Riopelle RJ, Longo FM, Wcskamp G, Otten U, Valletta JS, Johnston MV (1989) Developmental regu- 
lation of nerve growth factor and its receptor in the rat caudateputamen. Neuron 3:655-664.

Ohmichi M, Decker SJ, Pang L, Saltiel AR (1991) Nerve growth factor binds to the $140 \mathrm{kd}$ trk proto-oncogene product and stimulates its association with the src homology domain of phospholipase $\mathrm{C}$ gamma1. Biochem Biophys Res Commun 179:217-223.

Ohmichi M, Decker SJ, Saltiel AR (1992) Activation of phosphatidylinositol-3 kinase by nerve growth factor involves indirect coupling of the trk proto-oncogene with src homology 2 domains. Neuron 2:769-777.

Persson H (1993) Neurotrophin production in the brain. Semin Neurosci 5:227-237.

Phillips HS, Hains JM, Laramee GR, Rosenthal A, Winslow JW (1990) Widespread expression of BDNF but not NT3 by target areas of basal forebrain cholinergic neurons. Science 250:290-294.

Raffioni S, Bradshaw RA (1992) Activation of phosphatidylinositol 3-kinase by epidermal growth factor, basic fibroblast growth factor, and nerve growth factor in PC12 pheochromocytoma cells. Proc Natl Acad Sci USA 89:9121-9125.

Richardson PM, Verge Issa VMK, Piopelle RJ (1986) Distribution of neuronal receptors for nerve growth factor in the rat. J Neurosci 6:2312-2321.

Ringstedt T, Lagercrantz H, Persson H (1993) Expression of members of the trk family in the developing postnatal rat brain. Dev Brain Res 72:119-131.

Shelton DL, Reichardt LF (1986) Studies on the expression of the B nerve growth factor (NGF) gene in the central nervous system: level and regional distribution of NGF mRNA suggest that NGF functions as a trophic factor for several distinct populations of neurons. Proc Natl Acad Sci USA 83:2714-2718.

Smeyne RJ, Klein R, Schnapp A, Long LK, Bryant S, Lewin A, Lira SA, Barbacid M (1994) Severe sensory and sympathetic neuropathies in mice carrying a disrupted Trk/NGF receptor gene. Nalure 368:246-249.

Snider W (1994) Functions of the neurotrophins during nervous system development: what the knockouts are teaching us. Cell 77:627-638.

Soltoff SP, Rabin SL, Cantley LC, Kaplan DR (1992) Nerve growth factor promotes the activation of phosphatidylinositol 3-kinase and its association with the trk tyrosine kinase. J Biol Chem 267:1747217477.
Springer JE, Robbins E, Meyer S, Baldino FJ, Lewis ME (1990) Localization of nerve growth factor receptor mRNA in the rat basal forebrain with in situ hybridization histochemistry. Cell Mol Neurobiol 10:33-39.

Steininger TL, Wainer BH, Klein R, Barbacid M, Clive Palfrey $\mathrm{H}$ (1993) High-affinity nerve growth factor receptor (Trk) immunoreactivity is localized in cholinergic neurons of the basal forebrain and striatum in the adult rat brain. Brain Res 612:330-335.

Sutter A, Riopelle RJ, Harris-Warrick RM, Shooter EM (1979) Nerve growth factor receptors: characterization of two distinct classes of binding sites on chick embryo sensory ganglia cells. J Biol Chem 254:5972-5982.

Swanson LW, Kohler C, Bjorklund A (1987) The limbic region. I. The septohippocampal system. Handb Chem Neuroanat 5:125-277.

Thomas SM, Hayes M, DArcangelo G, Armstrong RC, Meyer BE, Zilberstein $\Lambda$, Brugge JS, Halegoua $S$ (1991) Induction of neurite outgrowth by $\mathrm{v}$-src mimics critical aspects of nerve growth factor-induced differentiation. Mol Cell Biol 11:4739-4750.

Vale RD, Shooter EM (1985) Assaying binding of nerve growth factor to cell surface receptors. Methods Enzymol 109:21-39.

Vantini G, Schiavo N, Di Martino A, Polato P, Triban C, Callegaro L, Toffano $G$, Leon A (1989) Evidence for a physiological role of nerve growth factor in the central nervous system of neonatal rats. Neuron 3:267-273.

Vetter ML, Martin-Zanca D, Parada LF, Bishop JM, Kaplan DR (1991) Nerve growth factor rapidly stimulates tyrosine phosphorylation of phospholipase C-gamma 1 by a kinase activity associated with the product of the trk protooncogene. Proc Natl Acad Sci USA 88:56505654.

Weskamp G, Otten U (1987) An enzyme-linked immunoassay for nerve growth factor (NGF): a tool for studying regulatory mechanisms involved in NGF production in brain and in peripheral tissues. J Neurochem 48:1779-1780.

Whittemore SR, Ebendal T, Lärkfors L, Olson L, Seiger A, Strömberg I, Persson $H$ (1986) Developmental and regional expression of $\beta$-nerve growth factor messenger RNA and protein in the rat central nervous system. Proc Natl Acad Sci USA 83:817-821.

Zhou J, Holtzman DM, Weiner RI, Mobley WC (1994) Expression of TrkA confers neuron-like NGF-responsiveness on an immortalized hypothalamic cell line. Proc Natl Acad Sci USA 91:3824-3828. 